\title{
EDUCAÇÃO PELA ARTE: A AUTOEDUCAÇÃO NO PRÉ-ESCOLAR E NO 1. CICLO DO ENSINO BÁSICO
}

\section{ARTIGO ORIGINAL}

RODRIGUES, José Carlos Meneses ${ }^{1}$

RODRIGUES, José Carlos Meneses. Educação pela arte: A autoeducação no Préescolar e no 1.- Ciclo do Ensino Básico. Revista Científica Multidisciplinar Núcleo do Conhecimento. Ano 05, Ed. 08, Vol. 03, pp. 112-150. Agosto de 2020. ISSN: 24480959, Link de acesso: https://www.nucleodoconhecimento.com.br/educacao/educacao-pela-arte

\section{RESUMO}

O estudo emergiu no contexto da unidade curricular de Educação pela Arte inserida no Mestrado em Educação PE (Pré-escolar) e 1. CEB (Ciclo do Ensino Básico), com a partilha de alunas. As atividades proporcionadas no PE e no 1. CEB contribuem para a formação das crianças na construção dos próprios conhecimentos e saberes, estimulando a curiosidade, a imaginação e a criatividade; daí o papel desempenhado pela Educação pela Arte, veículo ideal para a autonomia e a autoeducação das crianças e alunos. Realçamos dois objetivos do estudo: associá-la à promoção da autoeducação e justificar a dimensão da Arteterapia em contextos escolar e não escolar. Socorremo-nos de uma metodologia qualitativa e quantitativa através de uma amostra de 151 docentes e alunos da instituição de ensino superior a que pertencemos. Responderam 56 indivíduos (37\% da amostra) ao inquérito, via Google Forms, modelo utilitário, mas com alguns constrangimentos na leitura de algumas dimensões. Registramos alguns resultados consideráveis: a Educação Artística ainda tem um impacto forte no sistema educativo; a Educação pela Arte conquista espaço num percurso onde a interdisciplinaridade, a multidisciplinaridade e a

\footnotetext{
${ }^{1}$ Doutorado e mestrado em História da Arte; licenciado em História; bacharelado em 1.․ㅡ Ciclo do Ensino Básico.
} 
transdisciplinaridade constituem um trajeto irreversível; a Arteterapia obtém uma apreciação elevada dos inquiridos, merecendo um estudo aprofundado. O RCAAP (Repositórios Científicos de Acesso Aberto de Portugal) e a Google Scholar foram as plataformas capitais para a solidificação da fundamentação teórica. Consideramos uma conclusão fundamental: as dimensões artísticas serão mais visíveis com um reforço posicional de base (educadores, professores e agrupamentos) mediante uma colaboração sólida nas Artes/Expressões de molde a alcançar-se um patamar elevado na Educação pela Arte, momento, entre outros, em que a criança sentirá os benefícios da autoeducação.

Palavras-chave: Educação pela Arte, Educação Artística, arteterapia, pré-escolar, 1.ำ Ciclo do Ensino Básico.

\section{INTRODUÇÃO}

O tema justifica-se para dar voz às artes - designadamente a Educação pela Arte -, facilitando a tarefa dos educadores, professores, alunos e encarregados de educação. A autonomia das crianças é um passo crucial para o seu futuro e da sociedade em atividades que estimulam e suscitam a curiosidade e a vontade de aquisição de novos conhecimentos.

Para o efeito, percorrem-se as artes e os contributos das Expressões/Artes nas Orientações Curriculares do Ensino Pré-escolar (OCEPE) e do programa do 1.ํㅡㄹ; incluímos a Arteterapia como elemento fundamental no processo de autonomia, com instrumentos simples ao alcance dos educadores, sem retirar o papel que o especialista desenvolve em casos de natureza específica. Os profissionais de Arteterapia/Psicoterapia intensificam o debate estético com o objetivo da vivência significativa pelos contributos da criatividade trazidos a lume dos benefícios produzidos nas sessões (CARVALHO, 2018).

Delimitamos o estudo ao contexto da unidade curricular Educação pela Arte inserida no Mestrado em Educação PE e 1.․․ CEB, com a partilha de alunas, sem olvidar que outras terminologias (Educação Artística, por exemplo) não obliteram os objetivos da 
primeira; consideramos as dificuldades existentes com os conceitos de interdisciplinaridade, primordialmente, pela resistência vigente que conduzem, constantemente, a reconsiderar a nossa atitude e os objetivos no campo das artes na formação dos educadores/professores.

Por isso, não omitimos questões delicadas no PE e no 1. CEB: docentes impreparados e docentes sem motivação para a área em questão; a priorização de resultados em detrimento da qualidade; e a escassez de pessoal docente e auxiliar. São constrangimentos que nos orientam para uma questão: Qual o papel da Educação pela Arte para a evolução do PE e do 1.ํㅡㄹ

Estipulamos objetivos para o estudo: a) associar a Educação pela Arte à promoção da autoeducação; b) avaliar a promoção das artes no ensino, incluindo a interdisciplinaridade, a multidisciplinaridade e a transdisciplinaridade e a realização de eventos; c) justificar a dimensão da Arteterapia em contextos escolar e não escolar; d) compreender o rendimento escolar com o desempenho nas atividades artísticas em contexto não escolar e em crianças com necessidades especiais.

Recorremos às Expressões Artísticas do plano de estudos do mestrado e, prioritariamente, à necessidade de reorientar os interesses das crianças e dos alunos em prol de atividades que proporcionem autonomia que comprometa uma desejada autoeducação. O objetivo é sair dos espartilhos tradicionais, oferecendo aos educadores e professores situações de verdadeira aprendizagem, partindo, por exemplo, da análise de uma obra artística (linha, círculo, cor...) e desenvolvendo atividades livres de forma que cada intérprete estime e seja valorizado pelo que faz. As artes, tradicionalmente, voltam-se para o ensino das técnicas e os princípios estético-científicos; são congruentes em pessoas com formação artística numa dada arte e pretendem a elevação espiritual da criança em direção ao Belo e ao Bem (SOUSA, 2003). As Expressões/Artes espoletam na criança os seus interesses para o desempenho de qualquer tarefa, fazendo com que a sua atenção e determinação aumentem; "[...] constroem os seus próprios textos e imagens e tornam-se conscientes de si próprias como autoras e construtoras de imagens" (HOHMANN e WEIKART, 1997 apud CANELAS, 2015, p.14). 
A Educação Artística oficializa-se na década de 1970 (VAZ, 2015), incorporando-se na educação escolar as atividades artísticas de uma forma menos honrosa; uma consequência foi a formação de professores polivalentes, profissionais em artes plásticas, música e artes cênicas num curso de curta duração (dois anos) que, na sala de aula, apresentavam técnicas descontextualizadas.

Em plena 2.. Guerra Mundial, o filósofo Herbert Read lançou a obra Education through Art (1943) que envolve a arte como parte integrante do próprio processo educativo que defende uma nova abordagem na transmissão do conhecimento, considerando as atividades de feição expressiva, criativa, artística e estética implícitas na formação integral e humanista da criança e do adolescente. O princípio emergiu, mas a aceitação, como novidade, é sempre morosa, além de, o autor, prosseguir a via do anarquismo - coação que não deixava vingar no meio educativo -, e viver num período de beligerância (KEEL, 1969).

Entretanto, a UNESCO, com a preocupação de aproximar os conceitos de Educação pela Arte e Educação Artística, relembra o direito à educação e à cultura dando voz a um conceito que pretendemos explorar na educação (CASALS, 2012), num processo colaborativo porque nos reinventamos e todos os dias voltamos para os diferentes lugares onde habitamos, produzindo cultura com as pessoas com as quais interagimos. Eis o inexorável processo de humanização onde as crianças dão os primeiros passos na escola, marcantes para toda a sua vida, num plano positivo se aqueles passos forem solidificados pelos ventos de uma pedagogia aberta à autoeducação. E a arte é um campo incomensurável para o requerido (FILHO; BULCÃO; BATISTA, 2019).

Mas não podemos negligenciar o facto de, durante muito tempo, ensinarmos arte pelo bem da arte, apreciação e interpretação de objetos de arte, objetos culturais e técnicas de expressão e comunicação artísticas, integrando conteúdos sobre a educação patrimonial, nomeadamente o patrimônio tangível e intangível para um entendimento da diversidade cultural. Perante este cenário, há que reformular uma pedagogia para as artes, mais próxima dos processos que artistas contemporâneos estão a usar numa envolvência social. São espaços colaborativos fundamentais para os educadores e 
professores numa abordagem artística conducente à educação pela arte, leivas que não podem tardar a surgir em função de uma mudança paradigmática imperiosa (EÇA, 2016).

Não dissociamos a Arteterapia do nosso estudo (nos seus dispositivos mais simples), caracterizada por Carvalho (2011 apud RIBEIRO, 2012) como um método de tratamento psicológico, incorporando no contexto psicoterapêutico mediadores artísticos. Costuma ser muito bem recebida nas escolas (nos escassos exemplos onde é utilizada), com a utilização das mais variadas técnicas: expressão plástica, musical, dramática, corporal. A sua utilização em contexto não escolar hospitalização, principalmente -, é imprescindível para uma recuperação mais rápida, com a interdisciplinaridade, elo indispensável no processo educativo.

Reiteramos uma das conclusões do estudo: as dimensões artísticas serão mais visíveis com um reforço posicional de base (educadores, professores e agrupamentos de escolas) mediante uma colaboração interdisciplinar sólida nas Artes/Expressões de molde a alcançar-se o patamar da Educação pela Arte, momento, entre outros, em que a criança poderá sentir os benefícios da autoeducação. $O$ estudo flui com os seguintes tópicos: fragmentos da arte pela educação; dos conceitos aos casos de estudo; metodologia; resultados, análise e discussão; e considerações finais.

\section{FRAGMENTOS DA ARTE NA EDUCAÇÃO}

Almeida Garrett (1799-1854) incluiu as Artes numa formação estética, fundando, em 1836, o Conservatório Nacional (escolas de Dramática, de Música e de Dança), prevalecendo a formação de artistas. No final do século XIX, o pedagogo Adolfo Coelho consagra o ensino artístico como um elemento básico na formação do homem (CÂMARA, 2007).

A 1.ㄹ República (1910-1926) - uma esperança perdida - integra as artes no sistema educativo com uma campanha pela Educação Artística liderada por João de Barros, poeta e pedagogo, com o princípio de que não há sociedade democrática que possa 
viver sem o culto da arte, ou seja, sem o ensino artístico não há educação da sensibilidade (CÂMARA, 2007).

Almeida Garrett, Adolfo Coelho e João de Barros são contribuintes da educação artística em épocas que a iliteracia era de 80\% (1. ․ República).

Herbert Read[1], na sua publicação Education through Art (1943), transmite um conceito simples e incisivo: "[...] a arte deve ser a base da educação". Outros autores seguem Read concordando, discordando ou aditando elementos para os seus conceitos. Aceitamos, tal como Keel (1969) o entendimento sobre a expressão artística como desenvolvimento da aprendizagem, usando a criatividade, a liberdade de expressão, o prazer de experimentar caminhos alternativos. Educar pela arte permite, igualmente, o desenrolamento do sentido crítico, da imaginação, da memória, da lógica, do poder de análise, da síntese e da reflexão. As diferentes formas de expressão - música, imagens, teatro, dança, pintura ou desenho -, permitem uma ambiência repleta de oportunidades de aprendizagem. Além da autoeducação, a criança desenvolve-se com o mundo e com o respeito pela diversidade.

São conceitos capitais, mas difíceis de concretizar pelas pressões da época, de ordem econômica e social, mas, principalmente, de mentalidade.

\subsection{ASSOCIAÇÃO PORTUGUESA DE EDUCAÇÃO PELA ARTE}

A obra de Herbert Read tem reflexos em Portugal, com a criação da Associação Portuguesa de Educação pela Arte (1956) - presidida pela professora Alice Gomes -, e com pedopsiquiatras como João dos Santos e Arquimedes da Silva Santos, pintores como Almada Negreiros e Nikias Skapinakis, musicólogos como João de Freitas Branco e Calvet de Magalhães, um dos principais promotores da Associação (SANTOS, 2013).

Registamos algumas linhas-orientadoras do movimento: i) A Educação pela Arte não visa prioritariamente a formação de artistas (embora o possa fazer), nem a formação de novos públicos (apesar de ter esse efeito), nem a facilitação de outras 
aprendizagens ditas mais acadêmicas (não obstante o faça, certamente). Mas o que visa realmente é contribuir para o desenvolvimento mais global da personalidade de todo o ser humano; ii) A Educação pela Arte implica uma pedagogia ativa, procura promover a criatividade da criança e do jovem, fomentando a sua expressividade e dela partindo para uma educação estética e para outras situações educativas; iii) a Educação pela Arte tem em conta o desenvolvimento afetivo, emocional, que muito interessou pedopsiquiatras como João dos Santos e Arquimedes (SANTOS, 2013).

\subsection{CALVET DE MAGALHÃES E A ESCOLA FRANCISCO DE ARRUDA (LISBOA)}

Na entrada da década de 70 do século XX, a Fundação Calouste Gulbenkian continua a ter um papel preponderante no Ensino Artístico e na Educação pela Arte, criandose em 1971 a Escola-Piloto (mais tarde designada Escola Superior) de Educação pela Arte já com foros de aceitação oficial.

Entrementes, Calvet de Magalhães continua à frente da Escola Francisco de Arruda, transformada em Escola Preparatória a partir de 1968. Como pioneiro que era, participou na maioria das experiências pedagógicas então ensaiadas, muitas vezes sendo mesmo seu promotor "[...] como as da coeducação, integração de alunos com necessidades educativas especiais, os $7^{\circ}$ e $8^{\circ}$ anos experimentais e a utilização de meios audiovisuais", tornando-a uma escola de referência.

Calvet de Magalhães abraçou a causa da Educação pela Arte, a expressão artística dos alunos, a arte como ponto de partida para outras aprendizagens, para enriquecimento individual e coletivo (SANTOS, 2013, p. 45-46):

Soube concretizá-la na organização da escola, desde as paredes cobertas de citações e de pinturas dos alunos - e que nenhum ousava estragar - do que ele bem se orgulhava - à abertura da escola aos pais, ao bairro, à comunidade através de sessões culturais aos Sábados de manhã; desde os clubes de interesses que promovia à importância que dava à palavra, às linguagens, à expressão dos jovens e à forma como aproveitava os interesses e talentos dos professores que contratava. 
Cremos que foi uma experiência que não teve o condão de disseminação e, como barreira, a não absorção por parte da tutela ministerial, cujos princípios do Estado Novo não se coadunavam com o espírito de liberdade que estava implícito nesta pedagogia da arte. Basta relembrar que os reitores e diretores eram figuras poderosas a nível escolar, com efetivos poderes junto de docentes e respetivo pessoal. Calvet de Magalhães (falecendo, tragicamente, em 1974, no local de trabalho), dirigiu uma escola no bairro da Ajuda (Lisboa), numa estranha interseção social a paredes meias com habitações de classe média, palacetes de alta burguesia e bairros de lata, a escola Francisco de Arruda "era um verdadeiro milagre de experimentalismo pedagógico"[2].

\subsection{ARQUIMEDES DA SILVA SANTOS NA ESCOLA SUPERIOR DE EDUCAÇÃO PELA ARTE}

Enquanto nos anos 70 do século XX, o Canto Coral e o Desenho eram as disciplinas artísticas dos currículos escolares (CÂMARA, 2007), a Escola Superior de Educação pela Arte manteve-se entre 1971 e 1981 no Conservatório Nacional, com o contributo essencial de Arquimedes da Silva Santos, cuja disciplina de Psicopedagogia da Expressão Artística (1973-1974) apresentava, no primeiro tópico, Visão Genérica da Educação pela Arte, repetindo-se em 1979/1980 (MEIRA, 2015). Os candidatos eram admitidos com a idade mínima de dezasseis anos (com o 7.ำ ano dos liceus). A direção de 1971/1972 reconhecia que a função da Escola "[...] inseria-se numa missão humanística da Educação pela Arte [...] numa concessão de Escola Superior, aberta e livre [...] a única compatível com uma ação pedagógica pela Arte". (SANTOS, 2013 apud MEIRA, p. 2015, p. 52). Em 1972/1973, nos resultados de inquéritos realizados junto de alunos, o projeto-piloto de três anos era considerado favorável sendo possível, através da arte, "[...] termos uma intervenção pedagógica junto de crianças e adolescentes além de termos adquirido novas perspetivas para a mesma" (SANTOS, 2013, I, p. 19 apud MEIRA, 2015, p. 57-58). As saídas profissionais eram um óbice para o sucesso do projeto, bem como o reconhecimento jurídico e os conflitos emergentes no pós-25 de abril de 1974 (MEIRA, 2015). Com ascendentes e recuos, a Escola de Formação de Professores de Educação pela Arte é confrontada 
com um despacho ministerial onde se regista que, no ano letivo de 1980/1981, não seriam permitidas matrículas a novos alunos (MEIRA, 2015). Não obstante uma última tentativa de reorganização, em 1981, Madalena Perdigão reconhece que o valor educacional das artes esbarrava perante a recusa da sua inclusão no mais elevado nível de ensino - citando Meira (2015).

Calvet de Magalhães e Arquimedes da Silva Santos sonharam, tentaram e concretizaram, mas os olhares de "topo" e da "base" cruzaram-se no mesmo objetivo, qual ponto de fuga: o que é novo transtorna hábitos e mentalidades; desenvolver o espírito crítico e a autonomia de crianças e jovens é um propósito exequível apenas em pequenos campos, cujas cercas não permitem a almejada disseminação no sistema educativo.

Foram projetos pedagógicos que poderiam ter alterado o nosso sistema educativo, ao nível do ensino básico, principalmente. Calvet de Magalhães teve um fim trágico; Arquimedes da Silva Santos conduziria à expansão da Educação pela Arte, sua grande linha-orientadora, mediante a formação de profissionais especializados.

Paralelamente, dominava o tradicionalismo, imposição que não passava de experiências artísticas das crianças com as práticas de Lavores, Desenho Geométrico ou Livre - síndromo do Estado-Novo enraizado em mentalidades que não absorviam conceitos educativos consonantes com uma nova era!

\subsection{ERRÂNCIA DA EDUCAÇÃO PELA ARTE OU A AUSÊNCIA DE UMA PEDAGOGIA CONSISTENTE}

O fracasso da Escola Superior de Educação pela Arte foi uma prova de interesses inauditos, vagueando a Educação pela Arte nas ondas de personalidades investidas em cargos decisórios por mandatos, não dando continuidade ao que tinha condições para o sucesso.

Sousa (2003) afirma que a Educação pela Arte propõe o desenvolvimento da expressão artística e a Educação para a Arte visa a formação de artistas profissionais, 
processando-se através do ensino artístico. Enaltecem-se dois conceitos que, com o tempo, levariam à clarificação; a suspensão da Escola Superior de Educação pela Arte, em 1981 (MEIRA, 2015) - onde pontificou Arquimedes da Silva Santos -, anulou um projeto fundamental da Educação, facto que demonstra as dificuldades da imposição da Educação pela Arte já num período de democracia onde, quantas vezes, se perdem oportunidades por razões ideológicas (políticas).

A Lei de Bases do Sistema Educativo - Dec.-Lei n.ำ 46/86, de 14 de outubro - promove a Educação Artística (CÂMARA, 2007) (4. a fase da História da Arte do nosso sistema educativo - Sousa, 2003, I), que é aceite como fator importante na formação integral da pessoa, nos currículos do Pré-Escolar, Ensino Básico, Ensino Superior, Ensino Extraescolar e Ensino Especial. Promovem-se as capacidades de expressão, a imaginação criativa e a atividade lúdica; a Educação Artística e as diversas formas de Expressão Estética "[...] são um fator importante na formação integral da pessoa, devendo, por isso, fazer parte integrante do sistema de ensino" (CÂMARA, 2007, p. 47).

Perde-se o sentido da Educação pela Arte que reemerge no Dec.- Lei da Educação Artística (n. 334/90, de 2 de novembro), com a diversidade das áreas de Expressão e Educação Musical, Expressão e Educação Dramática, Expressão e Educação Plástica, Expressão e Educação Motora. Catorze anos depois, o Dec.-Lei 74/2004, de 26 de março, considera ainda a implementação do Sistema das Escolas a Tempo Inteiro, com atividades de enriquecimento, incluindo as de carácter artístico (CÂMARA, 2007).

Em 2003, Sousa levantara a questão da formação dos professores que tinham a responsabilidade da Educação Artística, registando a criação recente [1994] do Movimento Português de Intervenção Artística e Educação pela Arte (MOVEA)[3], que privilegiava a formação do indivíduo enquanto elemento de um coletivo social, na linha do que se designa por Educação pela Arte[4].

Deduzimos que a Educação pela Arte, desde os anos 50 do séc. $X X$, circulou ao sabor dos decisores ministeriais não se impondo como metodologia a seguir numa 
perspetiva de autoeducação, independentemente de se abordar no Estado Novo ou no pós-25 de abril de 1974. E se algo tem brotado é às bases que devemos, ou seja, fruto do trabalho de educadores e professores que pretendem exercer o seu múnus com a convicção de que a nossa era é de centrar toda a atenção em cada criança e aluno, fornecendo as ferramentas da autonomia e consequente autoeducação - além, naturalmente, dos casos de Calvet de Magalhães e Arquimedes dos Santos Silva, entre outros.

Teremos a resposta com o Plano Nacional das Artes?[5]. Eis o projeto dos Ministérios da Cultura e da Educação para o horizonte temporal 2019-2029 através da Resolução de Conselho de Ministros n.. 42/2019, de 21 de fevereiro, envolvendo artistas; comunidade educativa; instituições culturais; outros organismos governamentais; autarquias; fundações; instituições de ensino superior; meios de comunicação social; associações e coletividades; outros parceiros públicos e privados. Os fundamentos radicam na autonomia e flexibilidade curricular que vêm possibilitar às escolas uma gestão própria do currículo dos ensinos básico e secundário; as artes podem ser incorporadas nas matrizes curriculares-base, bem como o que tem sido promovido pelo Programa de Educação Estética e Artística, pelos Planos Nacionais de Leitura e de Cinema e pelas Redes de Bibliotecas Escolares e Portuguesa de Museus - unidos numa estratégia comum que é a missão do Plano Nacional das Artes.

Desconhecemos andamentos, passado mais de um ano, e a possibilidade de sucesso da Educação pela Arte, pois já existe um Programa de Educação Estética e Artística...

\section{DOS CONCEITOS AOS CASOS DE ESTUDO}

\subsection{EDUCAÇÃO ARTÍSTICA E EDUCAÇÃO PELA/PARA A ARTE}

Advertimos que a fundamentação teórica tem continuidade em 4. Resultados, análise e discussão, por opção metodológica, tornando este passo prático mais sólido. Iniciamos com Sousa $(2003, \mathrm{I})$, que considera quatro períodos no desenvolvimento das artes em Portugal: a) as Artes na Educação; b) uma Educação incluindo uma Formação Estética; c) a Educação pela Arte; d) e a Educação Artística. No índice 
(2003, I), o autor desenha a Educação Artística, incluindo: a) Arte e Educação; b) Educação Artística; c) Formação Estética; d) Educação pela Arte; e) Artes na Educação; f) Ensino Artístico.

A Educação Artística (4.ำ período) é ativada como o todo no índice, com as seguintes correspondências: Artes na Educação (1.ำ período) com Arte e Educação; Formação Estética e Educação pela Arte são comuns; no índice, é acrescentado o Ensino Artístico. Inferimos que o autor enfatiza Educação Artística e Educação pela Arte, ordem que os inquiridos confirmaram em primeiro e terceiro lugares (tabela-gráfico A1).

\subsection{EDUCAÇÃO ESTÉTICA E ARTÍSTICA: PROGRAMA DESTINADO AO 1. CEB}

A obra de Sousa (2003) incide em Educação pelas Artes e Artes na Educação, em três volumes. Enquanto nós pretendemos relevar a Educação pela Arte, não podemos arredar-nos de estudos e propostas que se distinguem na terminologia, mas que, basicamente, pretendem assumir uma mudança no campo das Artes/Expressões.

É o caso de Educação Estética e Artística no currículo do 1. CEB: uma via de concretização, que resulta do Programa de Educação Estética e Artística destinado ao 1.ํ CEB e, para consolidá-lo, um Plano de Formação de Professores. Herbert Read (1943, Educação pela Arte) não figura na bibliografia do estudo, por opção ideológica e, ou, metodológica, já que os autores se baseiam no processo legislativo do Ensino de Educação Estética e Artística do 1.․․ CEB que se encontrava legitimada por dois documentos - Decretos-Leis n. .9 139/2012, de 5 de julho, e n. 9 91/2013, de 10 de julho - anteriores à legislação vigente em 2017, altura da divulgação do estudo. O segundo merece-nos maior atenção porque se designava Metas de Aprendizagem das Expressões Artísticas, publicado em 2010.

Não obstante as inconsequências, os autores consagram "a estética e a arte como um campo disciplinar de pleno direito no currículo desse Ciclo", obedecendo a tempos 
letivos definidos, com conteúdos e objetivos/metas a alcançar exarados no DecretoLei n. 9 91/2013, de 10 de julho (MATEUS et al., 2017).

Na bibliografia domina a legislação produzida pelo Conselho Nacional de Educação, Ministério da Educação e Ministério da Educação e Ciência, não sem que haja uma fluidez de pensamento autônomo, como, por exemplo, as razões da inépcia pendente sobre a Educação Estética e Artística: i) a sobrevalorização da Matemática e do Português; ii) as concessões pedagógico-didáticas que tornam as crianças naturalmente inventivas e criativas, denotando iniciativa e autonomia, pelo que não é necessário passarem por um processo organizado de ensino; ora, enquanto os autores questionam tal pressuposto, nós colocamo-nos no lado oposto, pois é um dos princípios da Educação pela Arte; iii) uma terceira razão prende -se com a negligência do papel de Educação Estética e Artística no desenvolvimento cognitivo das crianças, em detrimento do desenvolvimento motor e afetivo (no sentido em que aquilo que executam tem de ter um significado individual). Sem negar estas duas últimas dimensões do desenvolvimento "[...] não se pode descuidar o facto de a investigação destacar o potencial da educação estética e artística na estruturação, desde idades precoces, de processos intelectivos" (FROÍS; MARQUES; GONÇALVES, 2000 apud MATEUS, et al. 2017, p. 235).

A proposta de Educação Estética e Artística releva o carácter multissensorial e interpretativo das diversas Expressões - Dança, Música, Artes Visuais e Drama/Teatro. O programa é apresentado como um meio para despertar os alunos para as grandes questões de que a estética e a arte se ocupam, levando-os a observar obras de arte, dialogar sobre elas e experimentar a partir delas (MATEUS; DAMIÃO; FESTAS, 2014, apud MATEUS, et al. 2017).

Concordamos com este percurso, porque é um dos princípios da Educação pela Arte, nomeadamente no PE, quando se dialoga sobre uma obra abstrata de Miró, por exemplo, e se pede às crianças que observem linhas e, a partir delas, elaborem o seu trabalho (desenho, colagens...): os alunos observam obras de arte desfrutando da diversidade de estímulos, orientados no diálogo argumentativo acerca do sentido ou sentidos que propagam, com destaque para o que cada atribui - sendo ainda 
convidados a explorar ideias e a manipular materiais diversificados, de forma a produzir algo (MATEUS; DAMIÃO; FESTAS, 2014 apud MATEUS, et al. 2017).

Os autores registam a formação de uma equipa de especialistas - Equipa de Educação Estética e Artística -, com base em programas reconhecidos internacionalmente, que concebeu o designado Programa de Educação Estética e Artística em Contexto Escolar; a sua implementação no 1.․ CEB, que era opcional por parte da escola e sempre feita por intermédio de professores não especialistas, abrangeu cerca de oitenta agrupamentos de escolas ao longo de todo o país. Desconhecemos os resultados, pois a intenção da equipa era avaliar o seu impacto em termos de aprendizagem após 2017, altura em que o estudo foi divulgado.

Depreendemos que Educação Estética e Artística não se diferenciam substancialmente de Educação pela Arte, facto que nos apraz registar, pois, por caminhos aparentemente distintos, chegamos ao objetivo: proporcionar às crianças um percurso de autoeducação através da arte.

\subsection{A SUSTENTABILIDADE DA EDUCAÇÃO ATRAVÉS DA ARTE}

Educação através da arte para um futuro sustentável é um estudo que agrega os campos educativo e social. Teresa Torres Pereira de Eça (2010) - sem recorrer a Read (1943) -, emprega as palavras-chave: educação artística; arte e educação; criatividade; educação para a cidadania; e desenvolvimento sustentável, que apoiam a nossa investigação.

A arte e a educação através da arte são campos que se interpenetram. Há artistas contemporâneos, educadores e professores que laboram em projetos sociais inominados integrando crianças e adultos de risco e especiais, presos e doentes; são artistas que trabalham em causas sociais, escapando-Ihes, como objetivo, o mercado de arte elitista, "[...] retomando o papel do artista xamã, providenciadas experiências de conhecimento de si e do mundo através da arte" (EÇA, 2010, p. 3). Do mesmo modo, há professores de Arte que escapam às metodologias conservadoras das escolas, ajudando os alunos com experiências transversais de aprendizagem com a 
arte e pela arte, sem a pretensão de formar artistas ou públicos, atingindo um futuro sustentável, onde os indivíduos sejam, antes de tudo, mais criativos, mais críticos e mais solidários.

Evidencie-se o peso econômico da cultura e das indústrias criativas para a qual a atuação do governo britânico em 2010 foi exemplar, implementando um currículo, onde a criatividade e a transdisciplinaridade eram os eixos essenciais e a arte e a educação artística tinham um espaço para fortalecer. Estas mudanças têm implicações muito grandes na definição da educação artística, porque, por natureza, o ensino através da arte e das culturas pode incluir os eixos transdisciplinares, quebrando as barreiras sem perder a sua especificidade. A arte conduz à promoção de uma vasta amplitude de qualidades criativas e capacidades críticas, podendo ser o centro do currículo, desde que os educadores artísticos reorganizem as suas práticas com o intuito de beneficiar tais objetivos (EÇA, 2010).

O Ano Europeu da Criatividade e da Inovação, em 2008, na sequência e continuidade do Ano Europeu do Diálogo Intercultural, no mesmo ano, são eventos que interpelam a criatividade que, raramente, se encontra no topo das prioridades escolares, já que, na maioria, domina um certo grau de conformismo, onde o jogo não entra; a escola é feita de "seriedade", com horários rígidos e prazos de entrega de trabalhos que não fomenta a vontade de explorar, não aceitando, por isso, comportamentos inconformistas e audazes (STEERS, 2008 apud EÇA, 2010, p. 3) .

Coincidimos com Eça (2010), na sua abordagem transversal e longitudinal, onde a educação através da arte fundamenta a construção de um futuro sustentável, pois promovem a criatividade, a inovação e o pensamento crítico, isto é, as capacidades fundamentais para uma cultura libertadora, de igualdade e responsabilidade social.

A educação através da arte, quando incide para a cidadania e para os valores, pode transformar o currículo e recriar a escola por meio de projetos transdisciplinares, quebrando as barreiras entre áreas do saber, havendo necessidade de rever e reformular os paradigmas atuais da educação e as abordagens através da arte e, 
acima de tudo, firmar fortemente na formação de educadores e professores (EÇA, 2010).

A educação artística e a promoção da criatividade e da inovação campeiam em estudos onde os alunos que seguiram um percurso com uma educação pela arte de bom nível em qualquer área (musical, visual, drama, dança), desenvolveram capacidades interpessoais e intrapessoais, sendo mais tolerantes, conseguindo "[...] usar pensamento divergente e convergente, são mais curiosos, mais abertos à mudança, não têm medo de arriscar e são mais críticos do que alunos que não tiveram acesso a programas de educação artística" (EÇA, 2010, p. 5). Mais: com base em estudos, a autora releva que uma educação artística de qualidade proporcionará capacidade de visão e de previsão, perseverança, mais capacidades lúdicas, mais propensão a aprender através dos erros, mais críticos e mais capazes de justificar as suas opiniões.

Eça (2010) questionou a promoção de um futuro sustentável mediante o desempenho da educação pela arte. Alfredo Palácios e Javier Abad Molina desenvolveram em Espanha um trabalho em que não há fronteiras entre o professor, o investigador e o artista nos diálogos críticos desencadeados nas comunidades onde emergiram os projetos, "[...] a partir de palavras e de imagens [...] (GARRIDO e MOLINA, 2008 apud EÇA, 2010, p. 5)". Paulo D'Alva fez um trabalho social numa comunidade cigana em Santa Maria da Feira (norte de Portugal) mediante um ateliê de cinema de animação (CARRO BRANCO CARRO PRETO apud EÇA, 2010). Uma arte-educadora brasileira - Lila Rosa Ferro -, colaborou no projeto "Awapa: nosso canto", a partir de uma rede de parcerias com o intuito de conservar a cultura Yaqwalapíti, no alto Xingu, por meio da preservação da música popular. No livro que Ferro (2008 apud EÇA, 2010) organizou para a comunidade Yawalapíti, a fala de Aritana sintetiza uma razão capital que a educação artística deve ter na educação: a passagem para os mais jovens.

\subsection{CLIO[6] NA ESCOLA COM A ARTE E CRIATIVIDADE}

Bahia (2010) assegura arte, criatividade, cultura, educação artística e memória como palavras-chave do seu estudo. Abordando educação para a arte (sem implicar Herbert 
Read na bibliografia) e para a cultura, embrenha-se nos saberes disciplinares da História de Arte e Criatividade que procuram também fomentar na teoria ou na prática uma educação para a Arte e para a Cultura.

Numa ambiência aberta, as questões convencionais desmaterializam-se com o uso da flexibilidade, da intuição, da espontaneidade e da imaginação; ao perseguirem a busca apaixonada do conhecimento do mundo exterior e interior, possibilitam que os outros se transformem e, em simultâneo, derrubem os mitos que inibem o desenvolvimento criativo e a sensibilização dirigida à apreciação crítica e estética do mundo (BAHIA, 2010).

Numa amostra de conveniência de 40 professores todos argumentavam que a História da Arte era fundamental para os alunos. Sendo 36 anos a média de idades num grupo de 25 homens e 15 mulheres, 23 de Humanidades e 17 de Artes, 21 professores relevaram o conhecimento, 8 a criatividade e 11 o conhecimento e a criatividade; mas capital é o facto de $80 \%$ dos docentes associarem o ensino da História da Arte ao conhecimento e apenas 47,5\% registrem a criatividade como fundamento-base (BAHIA, 2010). Esta conclusão explica a distância entre o ensino elitista e o que deveria desenvolver o crescimento das crianças a favor da autonomia, ou seja, do espírito crítico tão necessário à autoeducação.

A mitologia é um recurso para Bahia (2010) - uma clio que inspire; assim, imbuído com o espírito da criatividade e o conhecimento da Arte, o professor de História de Arte ou de qualquer outra disciplina, conforma aos seus alunos prazer do nobre conhecimento e continuem a olhar tudo o que os rodeia com curiosidade e interesse.

Independentemente da terminologia usada - Educação pela/para a arte, Educação Artística - aquele facto prova as dificuldades que os educadores e professore do $1 .$. CEB podem demonstrar; a evidência é o desacerto com a criatividade! Assim, assinalamos a nossa concordância com a autora no que tange à mudança de atitude de uma educação pela/para a arte ou educação artística. 


\section{METODOLOGIA}

A pesquisa foi enquadrada na unidade curricular de Educação pela Arte do mestrado em PE e 1. CEB, na Escola Superior de Educação em que lecionamos, com a participação de alunas.

Usamos o método qualitativo e quantitativo; devido à natureza rigorosa e meticulosa do primeiro, exige-se um aprofundamento na revisão da literatura e na elaboração de um plano de investigação equilibradamente delineado nos objetivos e na estruturação. A natureza metodológica qualitativa opõe-se à representação numérica, à análise estatística, à abordagem positivista, confirmatória e experimental oferecida pelos métodos qualitativos. O modelo quantitativo usa medidas numéricas numa rigorosa recolha de dados que, em fase posterior, são submetidos a análise estatística mediante paradigmas matemáticos, ou software apropriado (FREITAS, 2005).

A metodologia incidiu na análise documental da bibliografia digital dos Repositórios Científicos de Acesso Aberto de Portugal (RCAAP) e da Google Scholar e ainda em bibliografia física. Com um universo de 316 elementos (alunos e docentes da ESE onde decorreu o estudo) selecionamos uma amostra de 151 docentes e estudantes de Educação Básica, Mestrados e Especializações em Educação. Foi realizado um pré-teste a oito elementos de forma a podermos reorganizar questões que suscitassem dúvidas. Responderam 56 indivíduos (37\% da amostra) ao inquérito por questionário, via Google Forms, com as limitações relativas ao grau de profundidade da informação recolhida. A análise dos resultados não incluiu a codificação de respostas; o apuramento, o tratamento da informação e a elaboração das conclusões fundamentais verteram-se em 4.1 Resultados, análise e discussão.

O caso de estudo é a Educação pela Arte no PE e no 1.ํ CEB, preocupação comum a inúmeros docentes que entendem que as crianças, os educadores e os professores alcançariam patamares de aprendizagem incomensuráveis se fosse executada com a garantia de promover a sua autoeducação. Adiantamos que as Expressões/Artes já seriam cruciais para o efeito, almejando-se o nível mais elevado: a Educação pela Arte. A ordem educacional de autoestima e de autoeducação crescem 
exponencialmente com os instrumentos válidos que as crianças assimilam no PE e no 1. a CEB, alicerces e pilares de uma educação libertadora.

\subsection{RESULTADOS, ANÁLISE E DISCUSSÃO}

\subsubsection{ARTES NO ENSINO}

Tabela 1. Selecione a expressão que, na sua opinião, define a atualidade educativa

\begin{tabular}{|l|l|}
\hline Educação artística & $\mathbf{1 7}(\mathbf{3 7 , 0 \% )}$ \\
\hline Artes na educação & $12(26,1 \%)$ \\
\hline Educação pela arte & $11(23,9 \%)$ \\
\hline Ensino artístico & $04(08,7 \%)$ \\
\hline Formação estética & $02(04,3 \%)$ \\
\hline
\end{tabular}

Gráfico 1
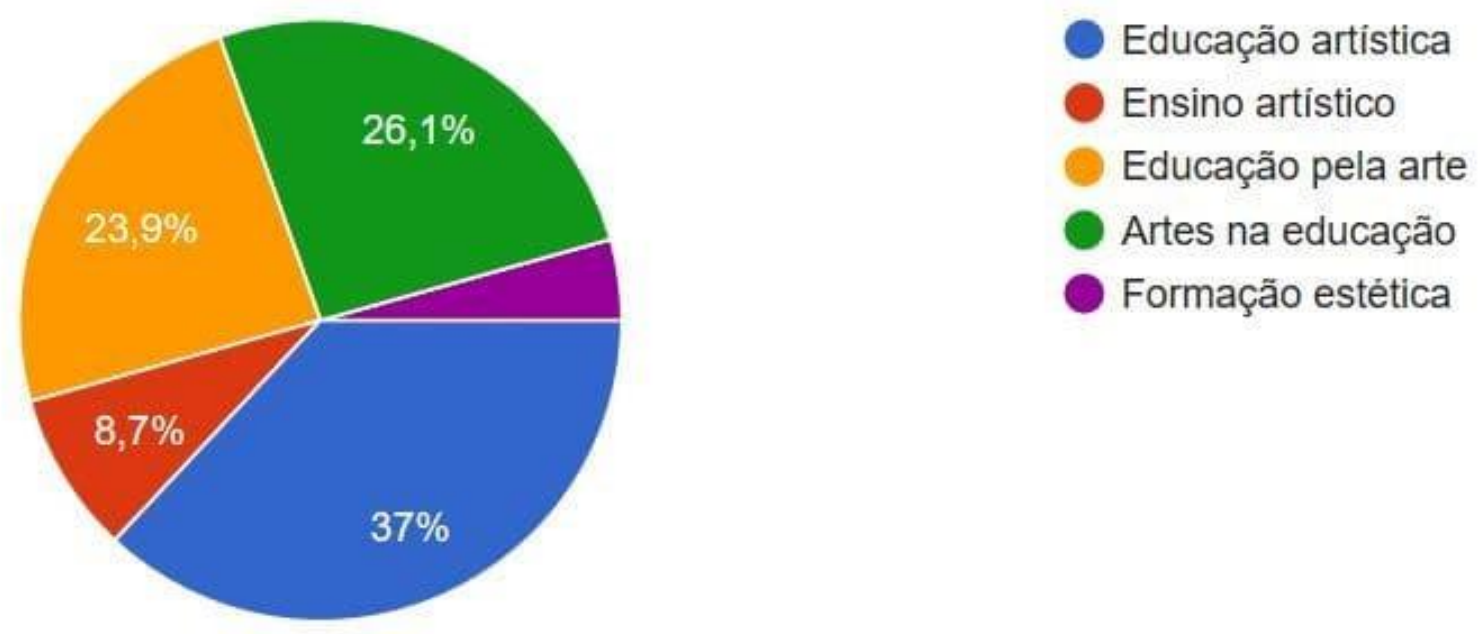

Fonte: dados obtidos no inquérito Google Forms

A supremacia pertence à Educação Artística (37\%); adicionando-a a Artes na Educação, obtemos 63,1\%. É o histórico legislativo do Sistema Educativo Português a imperar, restando o esforço dos docentes e uma abertura circunspecta à Educação pela Arte (23,9\%). Os resultados obtidos no Ensino Artístico $(8,7)$ e na Formação 
Estética $(4,3 \%)$ comprovam o desfasamento com a atualidade. Educação Artística e Artes na Educação $(63,1 \%)$ são imposições ministeriais que ainda dominam nas artes do ensino em geral. A Educação pela Arte $(23,9 \%)$ dá sinais de caminhar para a autoeducação.

Aditamos A Segunda Conferência Mundial de Educação Artística, acolhida em 2010 pelo Governo da República da Coreia, formando-se uma aliança entre ONG (Organizações Não Governamentais) - a International Society for Education through Art, a International Society for Music Education e a International Drama/Theatre and Education Association -, que criaram uma forte coligação para a proteção da Educação Artística e a redação de um roteiro para a mesma, onde se estruturam as políticas educativas. É um documento importante na defesa da Educação pela Arte/Educação Artística onde é delineada a estratégia fundamental para a aplicação com sucesso deste conceito no âmbito educacional (CASALS, 2012).

Tabela 2. Objetivos do processo educativo em artes

\begin{tabular}{|l|l|l|l|l|}
\hline Objetivos & & $\begin{array}{l}\text { Concordo } \\
\text { completamente }\end{array}$ & Concordo & Total \\
\hline $\begin{array}{l}\text { Consolidar o movimento e a } \\
\text { experiência }\end{array}$ & 20 & 19 & $39(85 \%)$ \\
\hline $\begin{array}{l}\text { Interpretar a liberdade e não } \\
\text { diretividade }\end{array}$ & 23 & 15 & $38(83 \%)$ \\
\hline $\begin{array}{l}\text { Aplicar o trabalho em equipa } \\
\text { Desenvolver a autoeducação }\end{array}$ & 26 & 14 & $40(87 \%)$ \\
\hline Traduzir a globalização e a inclusão & 27 & 17 & $39(85 \%)$ \\
\hline
\end{tabular}


Gráfico 2

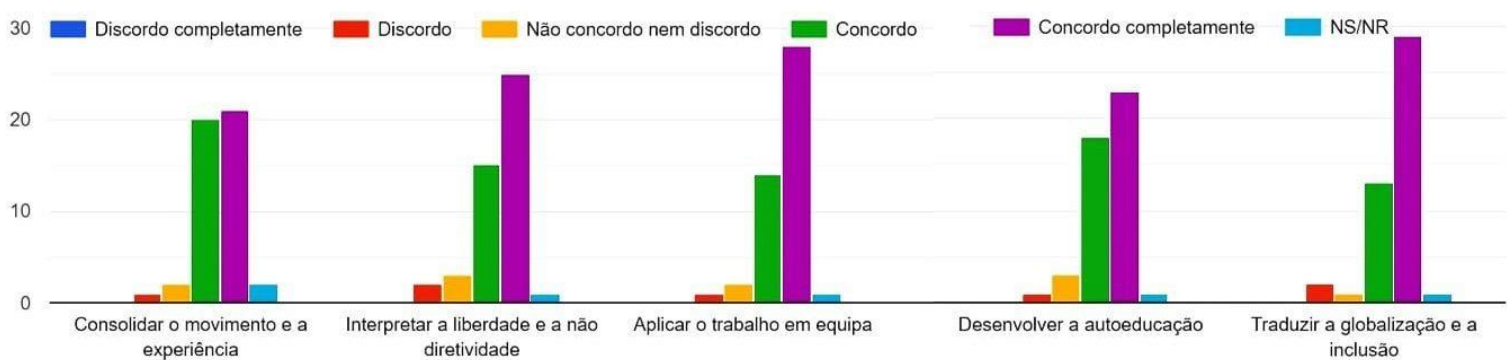

Fonte: dados obtidos no inquérito Google Forms

Os parâmetros aplicar o trabalho em equipa e traduzir a globalização e a inclusão (87\%) interligam-se com a atualidade e com o futuro. Entende-se por inclusão todas as alterações econômicas, sociais, saúde, e valoriza-se o trabalho em equipa numa altura em que as novas tecnologias individualizam a personalidade. Se avaliarmos os parâmetros consolidar o movimento e a experiência e desenvolver a autoeducação, testemunham-se valores similares (85\%). Os objetivos do processo educativo em artes estão adequados à atualidade do ensino, pelo menos, em respostas pedagogicamente corretas...

\subsubsection{INTERDISCIPLINARIDADE EM ARTES}

Tabela 3. Contributos para a promoção das Artes

\begin{tabular}{|l|l|l|l|}
\hline Atividades & $\begin{array}{l}\text { Concordo } \\
\text { completamente }\end{array}$ & Concordo & Total \\
\hline Expressão Musical & 35 & 09 & $44(95,6 \%)$ \\
\hline Expressão Dramática & 33 & 12 & $45(97,8 \%)$ \\
\hline Expressão Plástica & 33 & 09 & $42(91,3 \%)$ \\
\hline Expressão Motora & 33 & 12 & $45(97,8 \%)$ \\
\hline
\end{tabular}


Gráfico 3

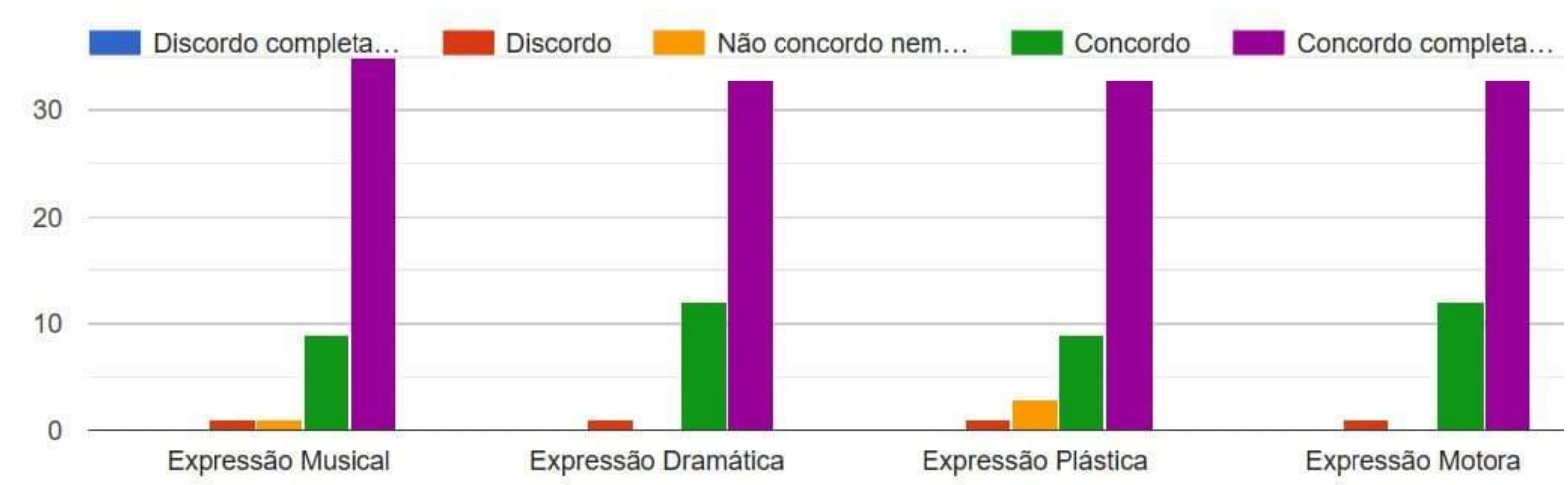

Fonte: dados obtidos no inquérito Google Forms

A opção inequívoca está em concordo completamente para as quatro expressões; no entanto, concordo completamente e concordo fornecem-nos uma percentagem semelhante $(97,8 \%)$ para a Expressão Dramática e para a Expressão Motora, seguindo-se a Expressão Musical (95,6\%) e a Expressão Plástica (91,3\%), resultado que surpreende - apesar de não ser substancial a diferença -, uma vez que se apresenta como uma das áreas mais trabalhadas no ensino e na Arteterapia.

A propósito, damos notícia de um projeto interdisciplinar, "A rua onde eu moro...", no 1. ${ }^{\circ}$ CEB" (GOMES, 2014, p. 46-48), na escola Básica de Vendas de Azeitão (Setúbal), que se desenvolveu em três etapas: 1. Português e Matemática; 2. Expressão Plástica mereceu realce em todas as etapas; 3. A Expressão Musical foi incluída na segunda e terceira etapas; 4. E as Expressões Físico-Motora e Dramática na terceira etapa.

O projeto vem ao encontro de Conceição (2015 apud CURRÍCULO NACIONAL, 2000 apud PEREIRA, 2012) que releva as Expressões como essenciais para o desenvolvimento pessoal, social e cultural da criança, devendo ser trabalhadas da mesma forma como as outras.

De igual forma? A autora (e tantos outros), como nós, predizemos esta postura correta, mas, como atrás expusemos, o terreno é íngreme e dificilmente arroteável! No entanto, uma experiência aqui e outra a seguir... deixarão um lastro suficiente para preencher, denodadamente, pelos educadores e pelos professores. 
No 1. CEB, a Expressão Plástica e Educação Visual; a Expressão e Educação Musical; a Expressão Dramática/Teatro; e a Expressão Físico-Motora/Dança mantêm a especificidade própria sendo trabalhadas, de forma integrada, pelo professor generalista, sob a designação de Expressões Artísticas. Garante-se, teoricamente, a articulação horizontal interdisciplinar e a articulação vertical no PE e nos subsequentes ciclos do Ensino Básico. Só que a realidade tem barreiras físicas e mentais que as escolas e a tutela demoram a dirimir a favor do lado mais humanista, mais consentâneo com os valores da nossa era. A narrativa pública (da tutela, dos formadores, dos pedagogos, dos agrupamentos) e legislativa estão interligadas, na generalidade, mas a realidade é outra, com generosas e honrosas exceções.

Se as Metas de Aprendizagem (DGIDC apud VAZ, 2015) poderiam cooperar na coadjuvação de professores especialistas das diferentes áreas artísticas, há constrangimentos para a Expressão Artística/Arte; para Piaget (1954 apud BAHIA, 2009 apud VAZ, 2015, p. 26) o maior obstáculo reside na família e no sistema tradicional de educação, que limita "[...] a espontaneidade natural da expressão artística que as crianças revelam precocemente não apostando na literacia simbólica, visual e artística e pensamento criativo [...]”.

Concordamos com Piaget[7] numa tarefa muito simples, educativa, propulsionadora da autonomia da criança: quando uma criança começa a garatujar, devemos questioná-la sobre o significado dos seus "desenhos", fazer anotações, datá-los e formar um dossiê que ajude o educador do PE a compreender o seu estádio de desenvolvimento. É uma forma de diluir os fossos existentes na trilogia escola-famíliasociedade, porque nós sabemos que a Escola portuguesa tem vivências extraordinárias em todos os campos, notadamente nas Artes/Expressões. Faltará o impulso e a exposição pública das exceções para que se generalizem.

Tabela 4. Discrimine a sua participação em atividades/eventos - até ao máximo de cinco - indicando o seu grau de satisfação

\begin{tabular}{|l|l|l|l|l|l|}
\hline Atividade & Bom & $\begin{array}{l}\text { Muito } \\
\text { bom }\end{array}$ & Subtotal & Razoável & Total \\
\hline
\end{tabular}




\begin{tabular}{|l|l|l|l|l|l|}
\hline $\mathbf{1}$ & 15 & 12 & $27(64,2 \%)$ & $06(14,2 \%)$ & $78.4 \%$ \\
\hline $\mathbf{2}$ & 14 & 11 & $25(59,5 \%)$ & $08(19,0 \%)$ & $78,5 \%$ \\
\hline $\mathbf{3}$ & 14 & 09 & $23(54,7 \%)$ & $11(26,1 \%)$ & $80,8 \%$ \\
\hline $\mathbf{4}$ & 15 & 09 & $24(57,1 \%)$ & $08(19,0 \%)$ & $76,1 \%$ \\
\hline $\mathbf{5}$ & 12 & 10 & $22(52,3 \%)$ & $08(19,0 \%)$ & $71,3 \%$ \\
\hline
\end{tabular}

Gráfico 4

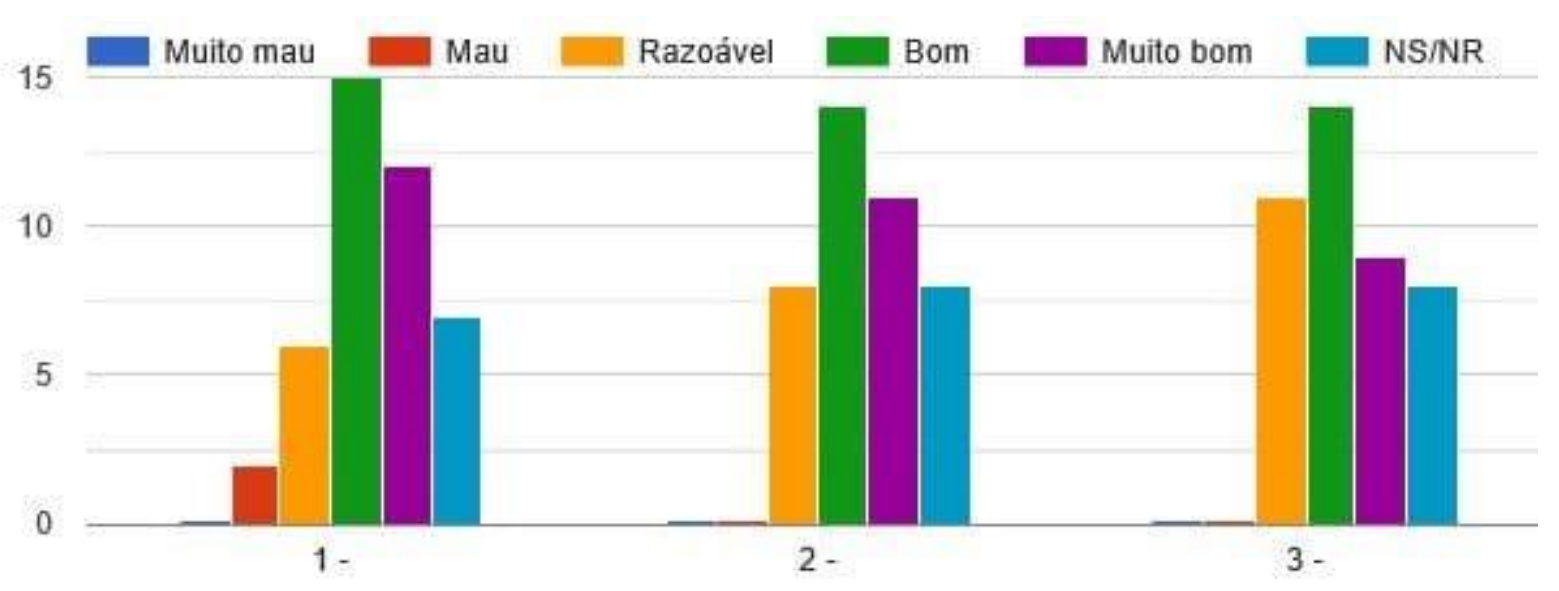

Fonte: dados obtidos no inquérito Google Forms

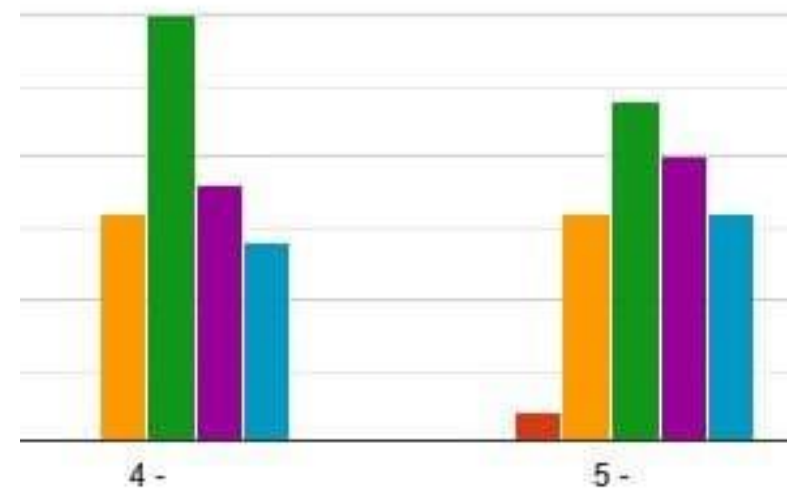

Fonte: dados obtidos no inquérito Google Forms

Não são mencionadas atividades nas propostas solicitadas. Nas dimensões bom e muito bom, destaca-se a atividade $1(64,2 \%)$, seguindo-se as restantes com uma diferença máxima de 11,9\%. Mau (6,5\%) surge apenas nas atividades 1 e 5 . Se adicionarmos a dimensão Razoável, a atividade 3 fica em primeiro lugar, seguindo-se 
as atividades 2 e 1, com uma pequena diferença. As atividades promovidas em contextos de aula e extracurricular apontam para um cenário positivo, quer a nível de professores (47,8\%), quer a nível de estudantes e trabalhadores-estudantes $(41,3 \%)$ e outra opção (10,9\%) (confrontar com a tabela-gráfico 15).

Há muito empenhamento a aguardar dos docentes que, irreversivelmente, percebem que nos encontramos numa época em que a sala de aula é uma parte fundamental da aprendizagem, mas jamais uma concha, porque os instrumentos são incomensuravelmente mais valiosos: o exterior e as tecnologias, designadamente as redes sociais onde cabe o telemóvel, com a abstinência ajustável de acordo com as regras estabelecidas na sala de aula.

No plano curricular do 1. CEB (VAZ, 2015), as Expressões Artísticas são lançadas para uma área inferior devido à atribuição de tempos mínimos para Português e Matemática e à impreparação dos próprios professores para as lecionar, mas recomenda-se que a Educação Artística tenha um lugar importante nos currículos e nos horários escolares, sendo reforçado nas situações de dificuldades na aprendizagem ou na integração escolar, exortação difícil de concretizar pela pressão familiar e social que exigem resultados céleres.

\subsubsection{ARTETERAPIA}

Tabela 5. É o tratamento psicoterapêutico que usa como mediação

\begin{tabular}{|l|l|l|l|}
\hline Expressões & Sim & Não & Talvez \\
\hline Musicoterapia & $33(75,0 \%)$ & $03(06,8 \%)$ & $08(18,1 \%)$ \\
\hline Dramaterapia & $26(59,1 \%)$ & $10(22,7 \%)$ & $08(18,1 \%)$ \\
\hline Dançaterapia & $27(61,3 \%)$ & $06(13,6 \%)$ & $11(25,0 \%)$ \\
\hline Expressão Plástica & $30(65,2 \%)$ & $07(15,2 \%)$ & $09(19,5 \%)$ \\
\hline
\end{tabular}


Gráfico 5

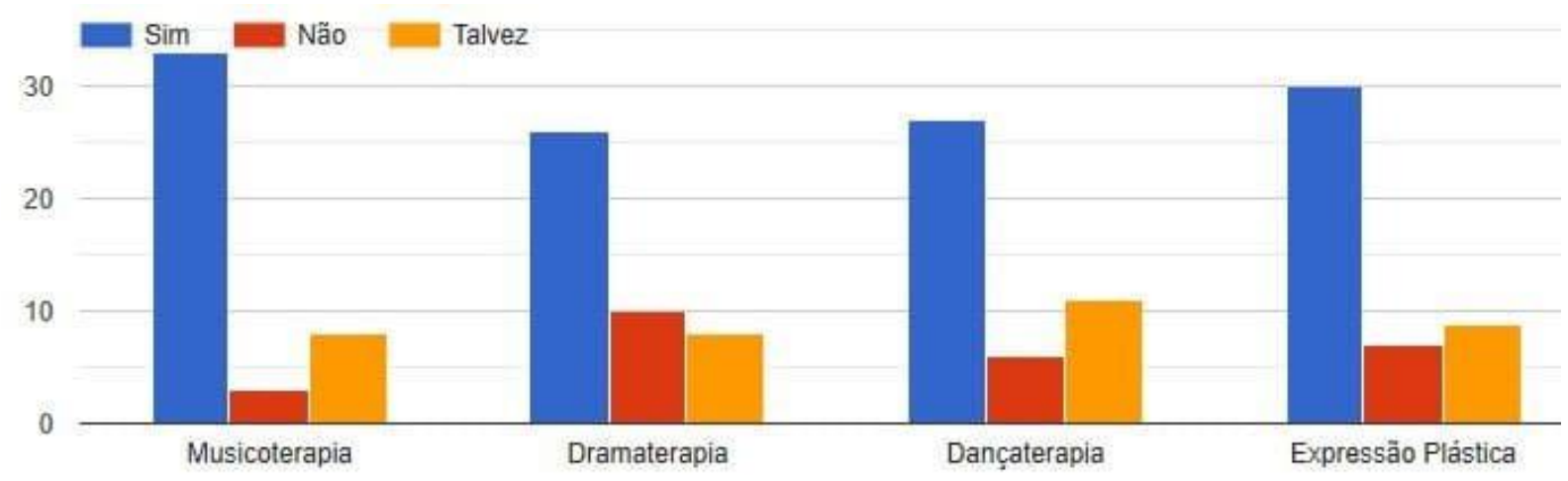

Fonte: dados obtidos no inquérito Google Forms

Os inquiridos optaram pela Musicoterapia (75\%) e pela Expressão Plástica $(65,2 \%)$, restando a Dançaterapia $(61,3 \%)$ e a Dramaterapia $(59,1 \%)$. Isto significa que as escolas devem apostar mais na Musicoterapia apesar de a Expressão Plástica ser a mais recorrente. Relativamente à opção não, a Dramaterapia (22,7\%) e a Expressão Plástica $(15,2 \%)$ são as mais escolhidas. Na opção talvez, é visível o destaque da Dançaterapia (25\%); a Musicoterapia e a Dramaterapia possuem a mesma percentagem (18,1\%), ou seja, os inquiridos revelam dúvidas na sua utilização, assim como na Expressão Plástica (19,5\%) - surpreendente como demos a perceber acima.

Vale a pena recorrer a Freud que não chegou a utilizar a arte como parte do processo psicoterapêutico (REIS, 2016). A Arteterapia foi descoberta na obra do pintor inglês Adrian Hill (Art vs Ilness, 1945), que utilizou o tempo de internamento para pintar: os médicos notaram uma recuperação mais rápida que os outros doentes. Jacobson (1974, p. 41 apud ROCHA, 2010, p. 18) declara que: “[...] há razões para querer que uma aplicação prudente destes princípios nas clínicas e nas escolas possa diminuir o desgaste do organismo humano e aumentar a eficácia humana”.

Para a Musicoterapia, um estudo com crianças autistas no Agrupamento de Escolas de S. Gonçalo B2, B3 (Torres Vedras), realizado por Monteiro (2017), valoriza a sua aplicação. O musicoterapeuta, em contexto escolar, integra uma equipa multidisciplinar: terapeuta da fala, fisioterapeuta, professor de educação especial, entre outros. $\mathrm{O}$ trabalho em equipa favorece os resultados finais (CUNHA, 2008 apud 
MONTEIRO, 2017): a música é fundamental para que o utente possa manifestar as emoções, os sonhos, as fantasias, as experiências físicas e as memórias. Há métodos para introduzir as canções num processo de musicoterapia (Lucas, 2012): a) reprodução/performance de canções, como forma de experienciar as emoções por elas expressas; b) composição de canções em grupo; c) partilha de uma canção gravada que expresse algo que o paciente queira comunicar sobre si próprio; d) análise da letra de uma canção, relacionando-a com a vida dos pacientes; e) criação de uma nova letra para uma música escolhida pelo grupo através da técnica dos espaços - técnica em que o terapeuta escreve parte das frases e os pacientes completam.

Quanto à Dramaterapia, os "jogos de fantasia" e de "faz-de-conta" - impropriamente chamados de jogo dramático ou expressão dramática - terão a sua origem na atividade lúdica da criança e não no teatro grego, como fazem crer alguns autores (AVELINO e BENTO, 1989 apud SOUSA, 2003, II, p. 22).

Em expressão dramática, a criança pratica a vida, está a fazer funcionar estruturas interiores emocionais muito importantes, desenvolve-se ao nível do domínio da ligação dos fenômenos imaginação/ação. A expressão dramática não é teatro, que parte de um texto e que é uma barreira para a criança. Em expressão dramática, a criança pratica a vida, está a fazer funcionar estruturas interiores emocionais muito importantes, desenvolve-se ao nível do domínio da ligação dos fenômenos imaginação/ação.

$\mathrm{Na}$ Dançaterapia, o objetivo recai sobre como nos sentimos interiormente ao contrário de como nos mostramos exteriormente (CERRUTO, s.d.)". Em 2003, Sousa menciona a organização programática das sessões de dança educativa de um plano de Arteterapia para escalões etários dos 3 aos 10 anos.

Na Expressão Plástica, o conhecimento das experiências descritas por Oliveira \& Santos (2004) - Arte/Expressão; Interação/Arteterapia; e Criatividade - conduzem o educador de infância a utilizar a Expressão Plástica de uma forma mais consciente, intencional e sistemática, correspondendo às OCEPE e à sua capacidade de liberdade de trabalhar com as crianças. Não concordamos totalmente, pois a menção às OCEPE constitui, por si só, uma atitude de apego ao oficializado, enquanto a 
flexibilidade curricular (atualmente em implementação) permite a liberdade de trabalho com as crianças.

Tabela 6. Avalie as vertentes de intervenção adequadas à Arteterapia

\begin{tabular}{|l|l|l|l|}
\hline $\begin{array}{l}\text { Área } \\
\text { intervenção }\end{array}$ & Importante & $\begin{array}{l}\text { Muito } \\
\text { importante }\end{array}$ & Total \\
\hline Saúde & 21 & 23 & $44(95,6 \%)$ \\
\hline Psicologia & 15 & 28 & $43(93,4 \%)$ \\
\hline Social & 16 & 29 & $45(97,8 \%)$ \\
\hline Educacional & 19 & 27 & $46(100,0 \%)$ \\
\hline Cultural & 18 & 25 & $43(93,4 \%)$ \\
\hline Artística & 19 & 22 & $41(89,1 \%)$ \\
\hline Ocupacional & 24 & 15 & $39(84,7 \%)$ \\
\hline
\end{tabular}

Gráfico 6

C2. Avalie as vertentes de intervenção adequadas à arteterapia

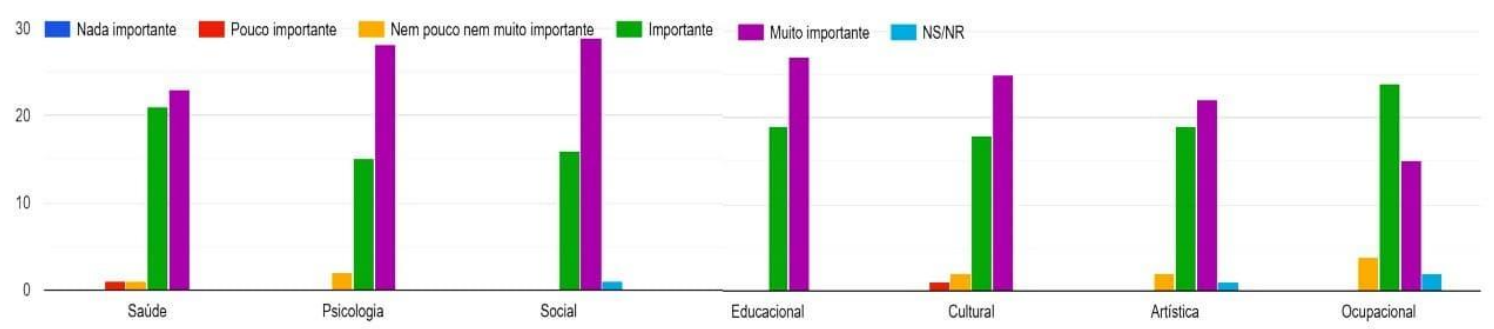

Fonte: dados obtidos no inquérito Google Forms

A opção centra-se na vertente educacional (100\%), seguida pela vertente social (97,8\%), da saúde (95,6\%), da psicologia e da cultura (93,4\%); às áreas selecionadas em último lugar, cabem a artística $(89,1 \%)$ e a ocupacional $(84,7 \%)$; o espaço percentual cifra-se apenas em $5,3 \%$.

A Arteterapia encontra diferentes aplicações na avaliação, prevenção, tratamento e reabilitação voltados para a saúde; o campo de atuação tem-se ampliado, mas de modo insuficiente. O "desenvolvimento da Arteterapia como área específica de 
trabalho deu-se na Psicologia" (REIS, 2016, p. 144). Presentemente, o mais importante é ampliá-la. Com formação adequada e recurso a especialistas? Claro, porque só assim é que os educadores e os professores poderão alimentar uma área tão necessária quanto as que fazem parte das OCEPE e do Plano Curricular do 1.. CEB.

Tabela 7. Arteterapia é um conceito familiar nas escolas do PE e do $1 . . \mathrm{C} E \mathrm{~B}$

\begin{tabular}{|l|l|l|l|}
\hline Atitude & No ensino PE & $\begin{array}{l}\text { No ensino do } \\
\text { Ciclo }\end{array}$ & Total \\
\hline Discordo completamente & $05(10.8 \%)$ & $04(0.88 \%)$ & $09(11.6 \%)$ \\
\hline $\begin{array}{l}\text { Discordo } \\
\text { Não concordo nem } \\
\text { discordo }\end{array}$ & $08(126.0 \%)$ & $12(26.6 \%)$ & $24(52.6 \%)$ \\
\hline $\begin{array}{l}\text { Concordo } \\
\text { Concordo } \\
\text { completamente }\end{array}$ & $11(24.4 \%)$ & $19(41.7 \%)$ \\
\hline NS/NR & $10(21.7 \%)$ & $06(13.3 \%)$ & $16(35.0 \%)$ \\
\hline
\end{tabular}

Gráfico 7.a

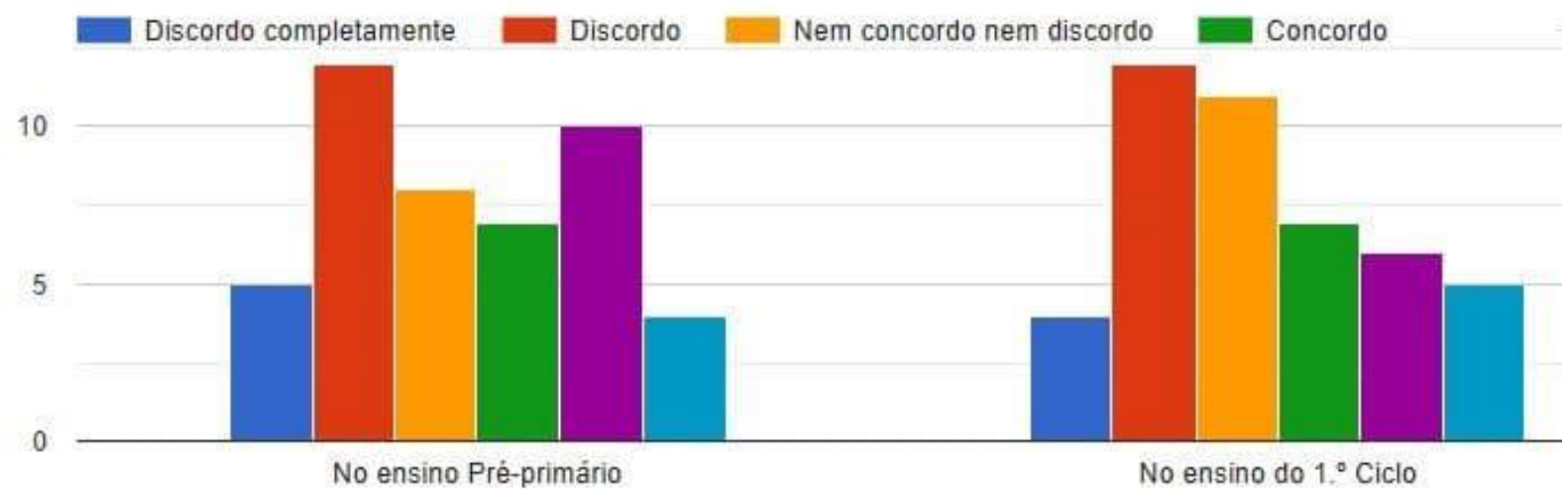

Fonte: dados obtidos no inquérito Google Forms 
Gráfico 7.b

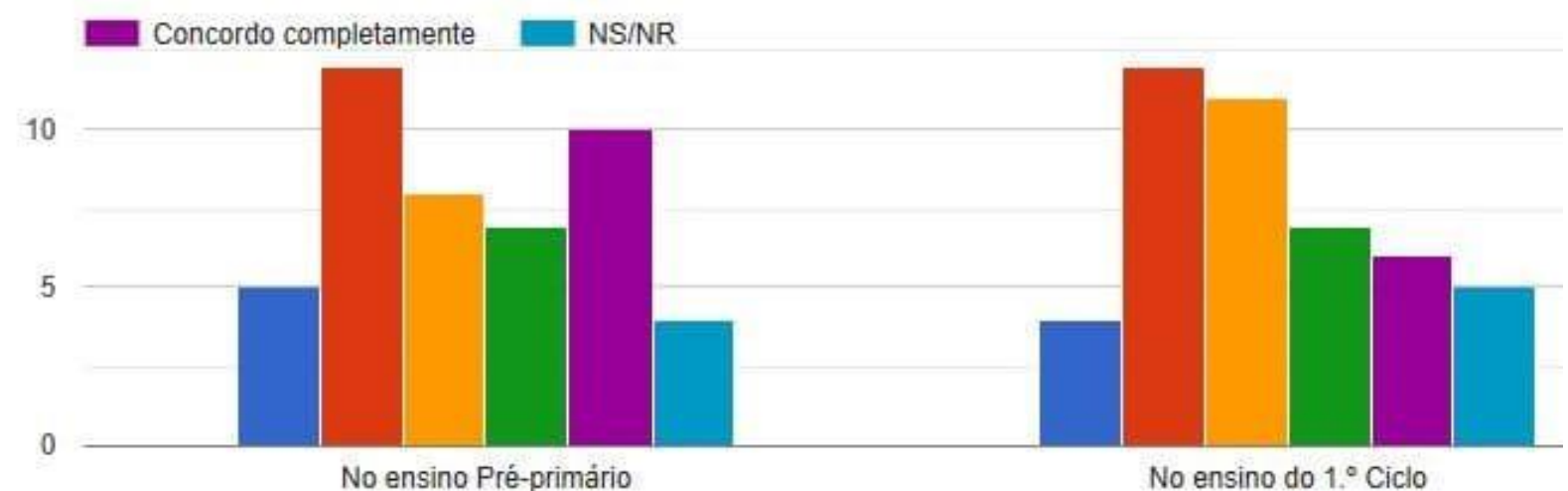

Fonte: dados obtidos no inquérito Google Forms

No PE, concordo completamente e concordo obtêm 36,9\%; se aditarmos não concordo nem discordo (17,3\%), as três dimensões cifram-se em 54,2\%. No cômputo geral, concordo completamente e concordo chegam a $65,7 \%$ enquanto discordo completamente e discordo atingem $64,2 \%$, repartindo-se, praticamente, como na análise individual. É uma dimensão a trabalhar com amplitude nestes dois níveis de ensino; as experiências ainda não são tão amplas quanto seria de exigir e a formação não permite que educadores, professores, pais e encarregados de educação possam valorizá-la adequadamente.

Tabela 8. Conhecimento de projetos de Arteterapia em contexto escolar

\begin{tabular}{|l|l|l|}
\hline Sim & 11 & $23,9 \%$ \\
\hline Não & 23 & $50,0 \%$ \\
\hline Talvez & 12 & $26,1 \%$ \\
\hline
\end{tabular}


Gráfico 8

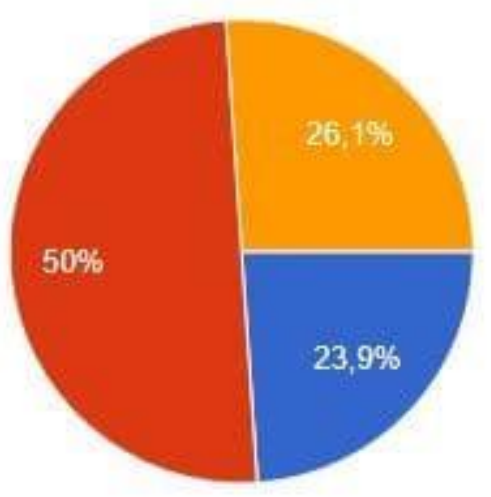

Fonte: dados obtidos no inquérito Google Forms

Metade dos inquiridos desconhece projetos de Arteterapia em unidades de ensino e $26,1 \%$ não tem a certeza de terem conhecimento sobre este assunto. Apenas $23,9 \%$ afirmam conhecer este tipo de atividades. A Sociedade Portuguesa de Arteterapia (SPAT) (http://arte-terapia.com/wp-content/uploads/2013/09/Revista-Arte-Viva-82018.pdf) contabilizou, em 2018, oito estabelecimentos de ensino a recorrerem a esta prática. Um início, afirmamos, mas é um registo que nos leva à crença de resultados amplos no próximo futuro.

Tabela 9. Conhecimento de projetos de Arteterapia fora do contexto escolar

\begin{tabular}{|l|l|l|}
\hline Sim & $\mathbf{2 3}$ & $\mathbf{5 0 , 0} \%$ \\
\hline Não & 15 & $32,6 \%$ \\
\hline Talvez & 08 & $17,4 \%$ \\
\hline
\end{tabular}


Gráfico 9

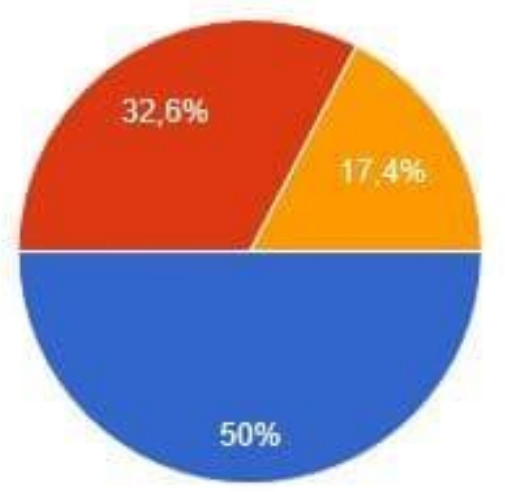

$$
\begin{aligned}
& \text { Sim } \\
& \text { Não } \\
& \text { Talvez }
\end{aligned}
$$

Fonte: dados obtidos no inquérito Google Forms

Fora do contexto escolar, metade dos inquiridos têm conhecimento de projetos em Arteterapia. Os que indicam as respostas não e talvez terão a ver com o facto de não existir informação suficiente acerca dos projetos ou por, simplesmente, não ser uma área que Ihes solicite a atenção.

\section{AS ARTES COM CRIANÇAS HOSPITALIZADAS}

Tabela 10. As artes com crianças hospitalizadas: a música, o desenho, a pintura, a dança, o canto e o desporto despertam interesses distintos nas crianças

\begin{tabular}{|l|l|}
\hline Nível 03 & $01(\mathbf{0 2 , 2} \%)$ \\
\hline Nível 04 & $13(28,3 \%)$ \\
\hline Nível 05 & $32(69,9 \%)$ \\
\hline
\end{tabular}


Gráfico 10

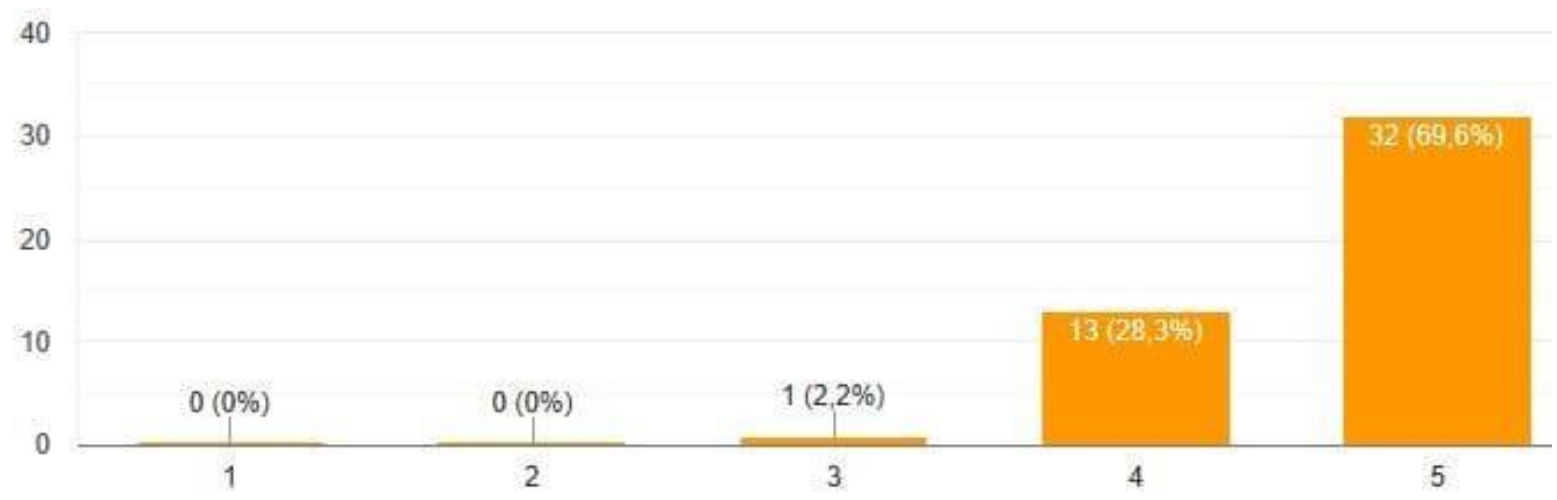

Fonte: dados obtidos no inquérito Google Forms

A maioria dos inquiridos $(69,6 \%)$ respondeu no patamar 5 , isto é, considerando que todas as áreas despertam interesses distintos nas crianças; cerca de $28,3 \%$ responderam no nível 4 e 2,2\% situaram-se no 3. nível.

Esteves (2013) garante que a realidade do processo de hospitalização da criança é sempre peculiar, pois deve-se levar em consideração a sua patologia, tratamento, pré e pós-cirúrgico. A concretização de atividades lúdicas faz com que as crianças fiquem menos ociosas e ansiosas através de ocupações já presentes no seu quotidiano antes da hospitalização. $O$ trabalho com artes tem o objetivo de desenvolver um atendimento integrado entre todos os profissionais, respeitando-se a multidisciplinaridade. - assevera Kryminice e Cunha (2009, p. 179-180 apud ESTEVES, 2013).

Estudar faz parte da hospitalização, mas a sua função é de mediar o mundo externo com a realidade presente da criança (PORTO, 2008 apud ESTEVES, 2013). Temos posições positivas e concordantes sobre o assunto, que apoiamos, pois, a recuperação de uma criança hospitalizada é tanto maior quanto os estímulos lúdicos e emocionais que absorve. Os avanços são ténues, sabendo-se que estamos perante uma questão de inclusão pelo direito à educação para crianças hospitalizadas, encontrando-se ainda à margem de políticas públicas voltadas para a necessidade de regularização desse atendimento. Há necessidade de promover nomenclaturas como classe hospitalar, hospitalização escolarizada, pedagogia hospitalar, escola 
hospitalar, entre outras, para uniformização, no âmbito nacional, e clarificação legislativa do poder central (SALDANHA e SIMÕES, 2013).

Tabela 11. O desempenho escolar melhora com as atividades artísticas

\begin{tabular}{|l|l|}
\hline Nível 02 & $\mathbf{( 0 1 )}$ \\
& $\mathbf{( 2 , 2 \% )}$ \\
\hline Nível 03 & $04(08,7 \%)$ \\
\hline Nível 04 & $12(26,1 \%)$ \\
\hline Nível 05 & $29(63,0 \%)$ \\
\hline
\end{tabular}

Gráfico 11

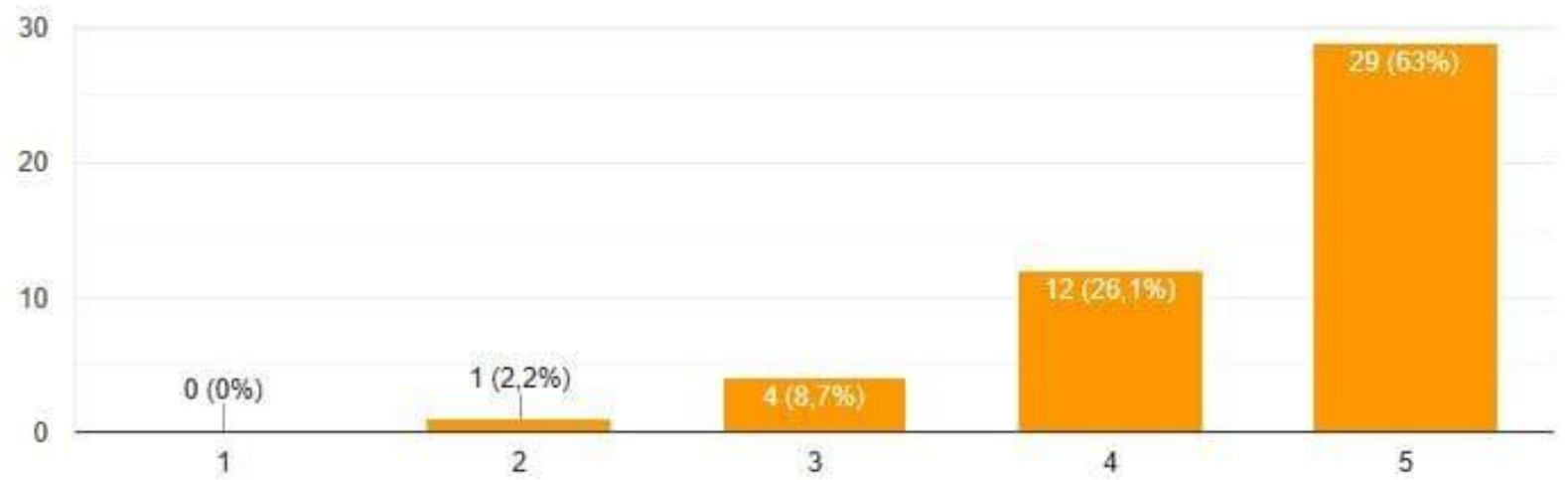

Fonte: dados obtidos no inquérito Google Forms

Concordo completamente (5) e concordo (4) totalizam 89,1\%. As atividades artísticas não só contribuem para o desenvolvimento da criança, como elevam a sua autoestima e capacidade de raciocínio; estes agentes concorrem para melhorias noutras matérias no concurso da interdisciplinaridade. Assim no-lo afirma Eisner (apud CATTERALL, 2012) observando que há trabalhos demais que se sustentam, havendo bastante interesse ativo nas possíveis relações entre o envolvimento das artes no ensino e o desenvolvimento de habilidades que contribuem para o sucesso escolar.

O lugar da arte na escola configura-se a partir de um currículo pré-estabelecido, que é redesenhado, discutido, reelaborado, enquanto vivido. As relações de poder implicam ampliação, alargamento e flexibilidade deste currículo rígido. O poder único 
legitimado pelo currículo prescrito "[...] é um passo para alocar a democracia em plataforma móvel, em risco [...]" (OLIVEIRA, 2012 apud FILHO; BULCÃO; BATISTA, 2019, p. 13).

Tabela 12. As atividades artísticas são uma prática a adotar em todas as unidades hospitalares destinadas a crianças

\begin{tabular}{|l|l|}
\hline Nível 02 & $01(\mathbf{0 2 , 2} \%)$ \\
\hline Nível 03 & $01(02,2 \%)$ \\
\hline Nível 04 & $16(34,8 \%)$ \\
\hline Nível 05 & $28(60,9 \%)$ \\
\hline
\end{tabular}

Gráfico 12

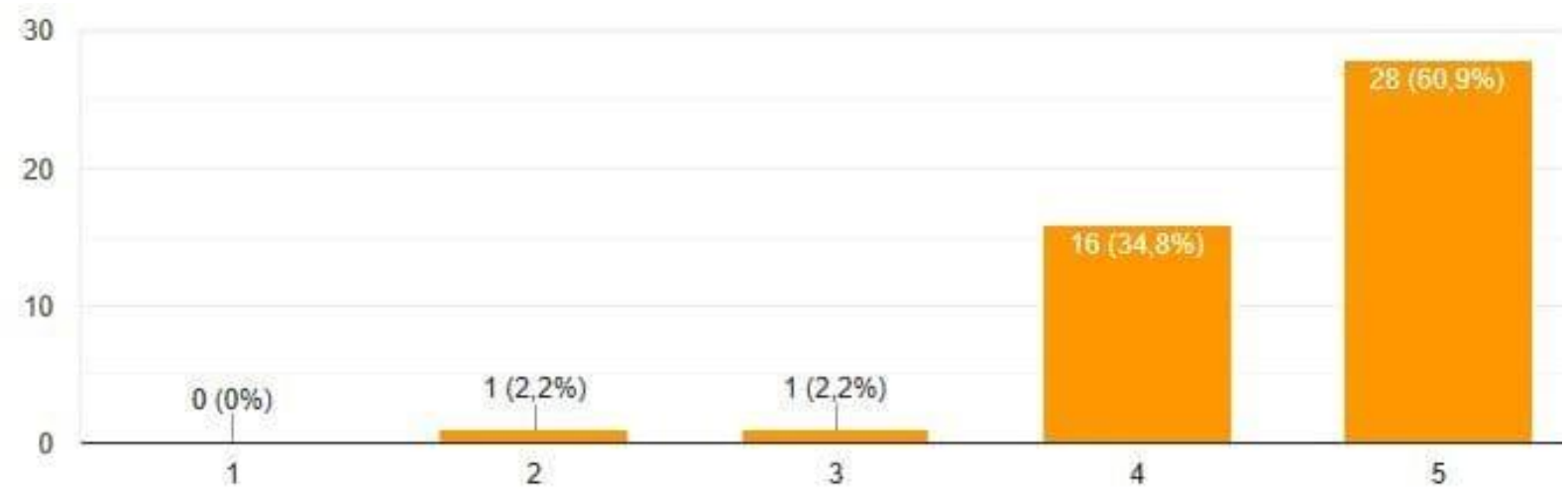

Fonte: dados obtidos no inquérito Google Forms

A maioria (60,9\%) concordo totalmente (5) assume que as atividades artísticas são uma prática a adotar em todas as unidades hospitalares destinadas a crianças, seguindo-se $34,8 \%$ que afirmam concordo (4), sendo apenas contrariados por $2,2 \%$, que negam esta necessidade. Sem opinião, declararam-se 2,2\%. Falta informação para identificar a opção dos $4,4 \%$ - nulo ou discordância.

Cruz (2012) indica que os hospitais podem ser ambientes estimulantes para a criança com atividades terapêuticas que permitam vivências idênticas às que teriam no seu ambiente normal. Valladares (2003, p. 66 apud CRUZ, 2012) alude ao papel da 
expressão pela arte: possibilita à criança fugir do desagradável, da dor e da ansiedade, monotonia e emoção intensa.

Não sendo uma prática generalizada (ausência de mentalidades abertas de administrações hospitalares, constrangimentos de instalações, dificuldades de suporte voluntário de especialistas, entre outros), há práticas que vão sendo expostas e com expansão, embora não de forma exponencial.

\section{O PAPEL DAS ARTES NO DESENVOLVIMENTO DE CRIANÇAS COM NECESSIDADES ESPECIAIS}

Tabela 13. PEA (Perturbação do Espetro do Autismo)

\begin{tabular}{|c|c|c|c|c|}
\hline Artes & $\begin{array}{l}\text { a) Não } \\
\text { concordo } \\
\text { nem discordo }\end{array}$ & $\begin{array}{l}\text { b) } \\
\text { Concordo }\end{array}$ & $\begin{array}{l}\text { c) Concordo } \\
\text { completamente }\end{array}$ & $\begin{array}{l}\text { Total } \\
\text { de } \\
\text { b) e c) }\end{array}$ \\
\hline $\begin{array}{l}\text { As artes e as } \\
\text { expressões } \\
\text { promovem } \\
\text { desenvolvimento } \\
\text { criança. }\end{array}$ & 03 (6.5\%) & $13(28.2 \%)$ & 30 (65.2\%) & $93.4 \%$ \\
\hline $\begin{array}{l}\text { A expressão plástica } \\
\text { permite } \\
\text { envolvimento dos } \\
\text { sentidos da criança, } \\
\text { sobretudo o tato e a } \\
\text { visão. }\end{array}$ & 04 (8.6\%) & $10(21.7 \%)$ & 32 (69.5\%) & $91.2 \%$ \\
\hline 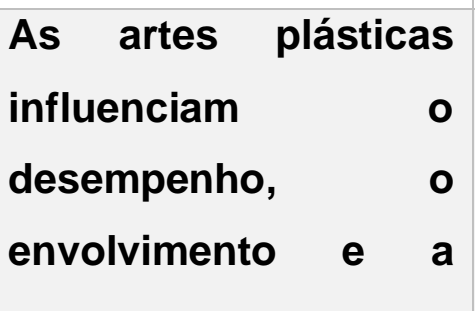 & 04 (8.6\%) & 15 (32.6\%) & $27 \quad(58.6 \%)$ & $91.2 \%$ \\
\hline
\end{tabular}




\section{imaginação da criança com PEA.}

\section{Gráfico 13.a}

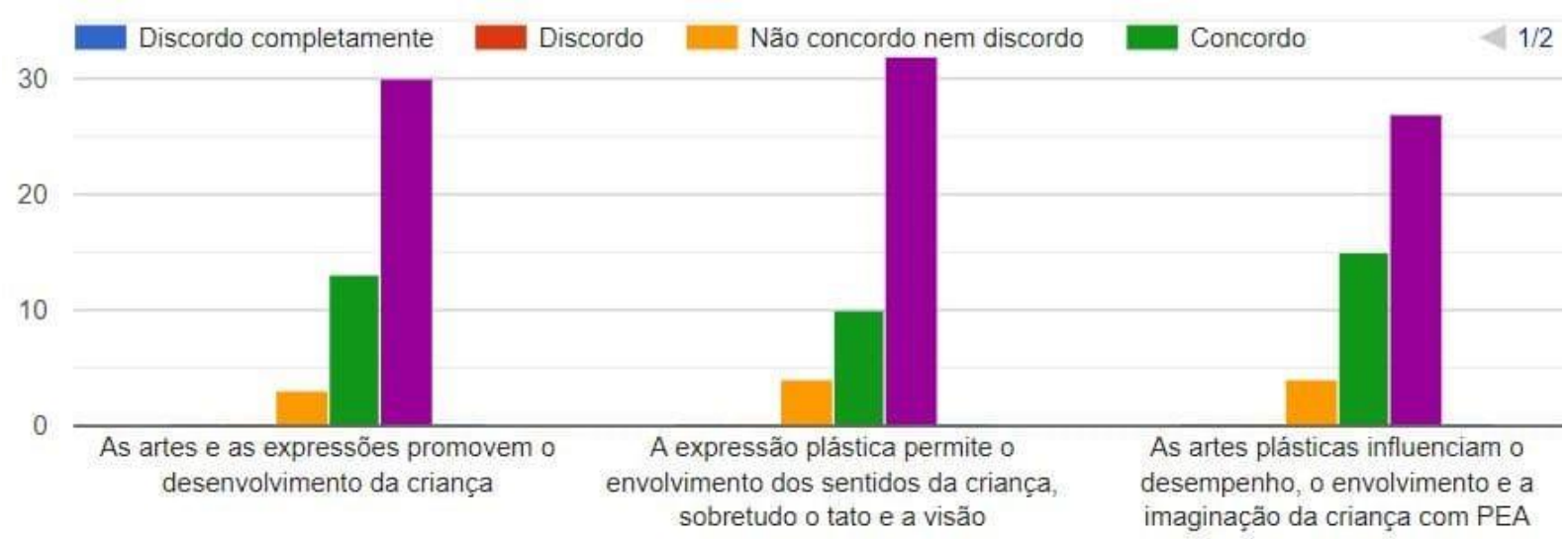

Fonte: dados obtidos no inquérito Google Forms

Gráfico 13.b

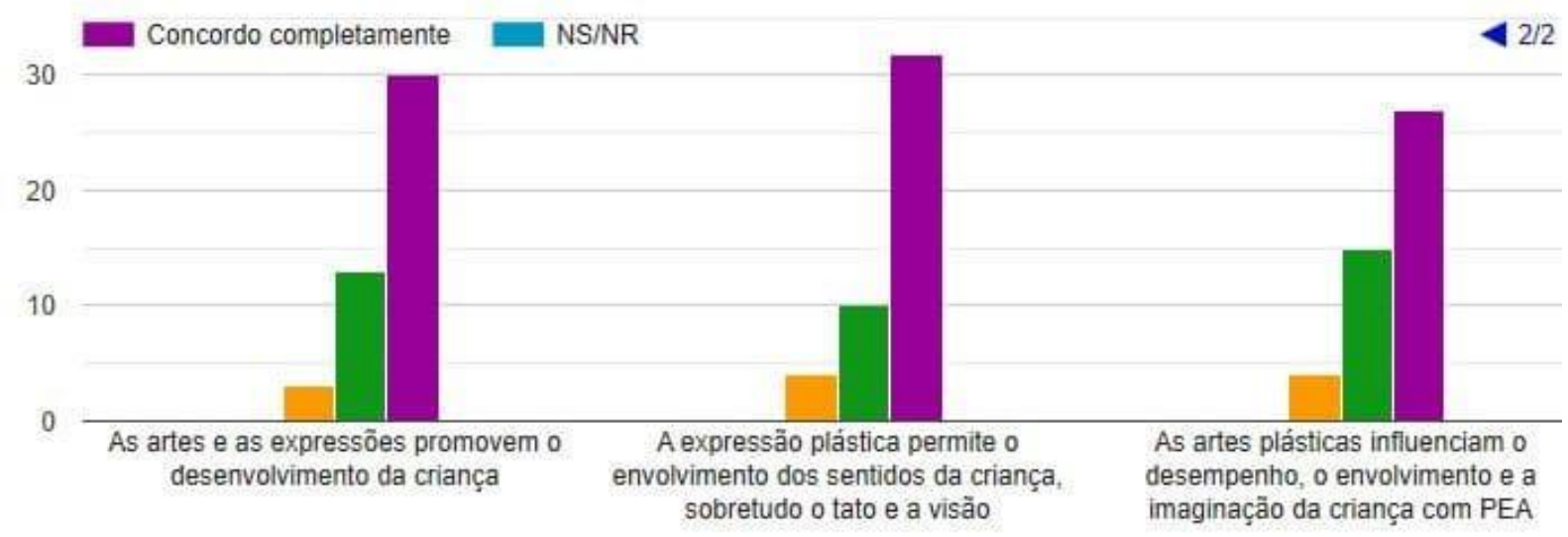

Fonte: dados obtidos no inquérito Google Forms

Agregando concordo e concordo completamente, a proximidade das três dimensões é notória, evidenciando-se um pouco acima As artes e as expressões promovem 0 desenvolvimento da criança (93,4\%), deduzindo-se que os inquiridos se situam num patamar de compreensão elevado relativamente às questões consideradas; ou seja, as artes têm um papel preponderante no desenvolvimento de crianças com necessidades especiais.

RC: 57230

Disponível em: https://www.nucleodoconhecimento.com.br/educacao/educacao-pela-arte 
Ao tornarem-se capazes de expressar a sua própria voz, os alunos serão capazes de se envolver na cultura, encontrando um lugar mais justo na sociedade - certifica MacLean (2008 apud VAZ, 2015). O esforço tutelar, ao nível legislativo, tem sido elevado, não correspondendo, na prática, ao desejável, porque não é acompanhado pela disponibilidade de pessoal docente, entre outros.

\section{PERFIL DO RESPONDENTE}

Tabela 14. Idade

\begin{tabular}{|l|l|l|}
\hline Até 20 anos & $\mathbf{0 4}$ & $\mathbf{0 8 , 7} \%$ \\
\hline $\mathbf{2 1 - 2 5}$ anos & 11 & $23,9 \%$ \\
\hline $\mathbf{2 6 - 3 0}$ anos & 03 & $06,5 \%$ \\
\hline $\mathbf{3 1 - 3 5}$ anos & 04 & $08,7 \%$ \\
\hline $\mathbf{3 6 - 4 0}$ anos & 05 & $10,9 \%$ \\
\hline $\mathbf{4 1 - 4 5}$ anos & 09 & $19,6 \%$ \\
\hline $\mathbf{+ 4 5}$ anos & 10 & $21,7 \%$ \\
\hline
\end{tabular}

Gráfico 14

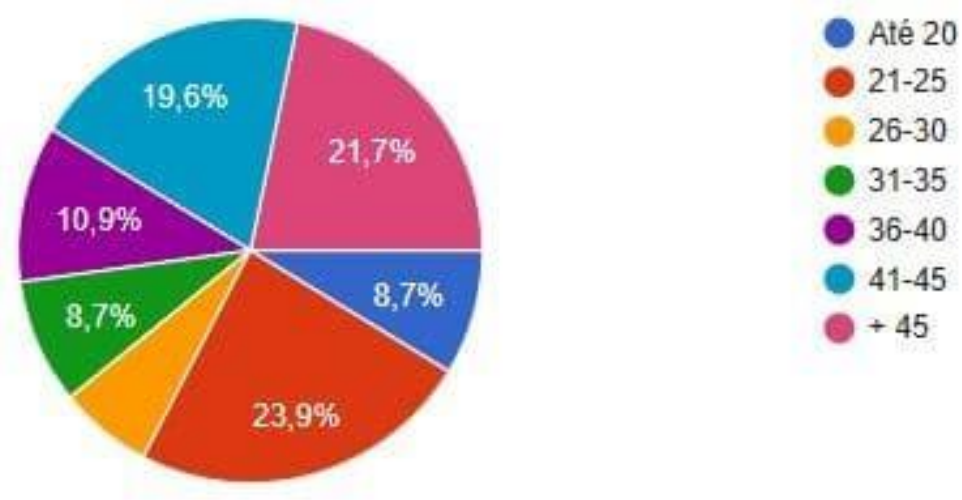

Fonte: dados obtidos no inquérito Google Forms

A faixa etária 21-25 anos (23,9\%) é dominante (11 inquiridos), como seria de esperar; a) se adicionarmos três grupos - "até 20" - (8,7\%), "21-25" (23,9\%) e "26-30" (6,5\%) atingimos 39\% (18 respondentes); b) unindo "31-35" (8,7\%) com "36-40" (10,9\%) 
chegamos a 19,6\% (9 respondentes); c) somando " $41-45$ " (19,6\%) com "+ 45" (21,7\%), obtemos $41,3 \%$ (19 respondentes), resultado que advirá dos professores que frequentavam as especializações na ESE. Os grupos etários respondentes mais jovens (39\%) e menos jovens $(41,3 \%)$ aproximam-se percentualmente.

Tabela 15. Atividade profissional

\begin{tabular}{|l|l|l|}
\hline Estudante & $\mathbf{1 3}$ & $\mathbf{2 8 , 3} \%$ \\
\hline Trabalhador-estudante & 06 & $13,0 \%$ \\
\hline $\begin{array}{l}\text { Educador } \\
\text { Professor 1. Ciclo (+ } \\
\text { desempregada) }\end{array}$ & 06 & $13,0 \%$ \\
\hline $\begin{array}{l}\text { Professor 2.. Ciclo } \\
\text { Professor IESF (+ colaborador } \\
\text { IESF) }\end{array}$ & 01 & $17,4 \%$ \\
\hline \begin{tabular}{l} 
Outra opção \\
\hline
\end{tabular} & 04 & $08,2 \%$ \\
\hline
\end{tabular}

Gráfico 15

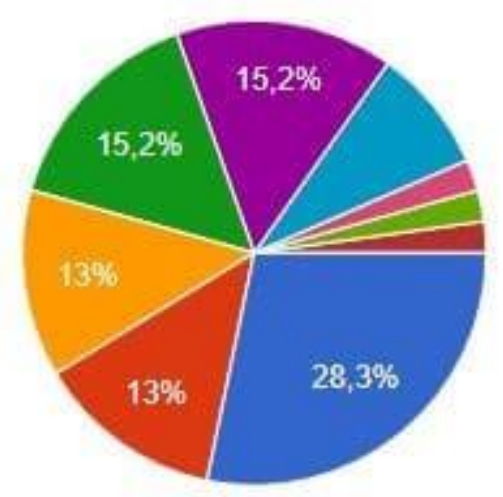

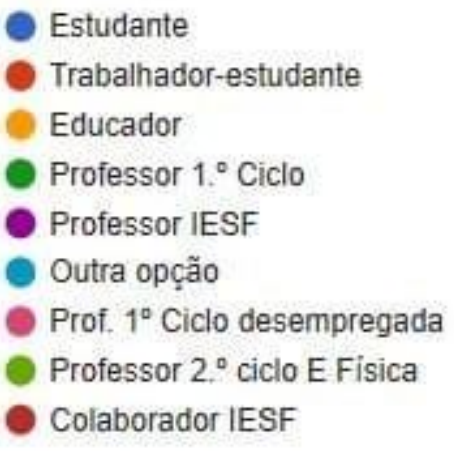

Estudante

Professor IESF

Outra opcão

Prof. $1^{\circ} \mathrm{Ciclo}$ desempregada

Professor $2{ }^{\circ}$ ciclo E Física

Colaborador IESF

Fonte: dados obtidos no inquérito Google Forms

Por ordem decrescente: estudante $-28,3 \%$; professor IESF - 17,4\%; professor 1..ำ CEB - 17,4\%; educador de infância - 13\%; trabalhador-estudante - $13 \%$; outra opção - 8,7\%; professor 2.․ Ciclo - 2,2\%. A maior porção $(30,4 \%)$ incide no conjunto 
professor $1 .^{\circ}$ CEB e educador; a "Outra opção" foi registada para situações de não emprego no Ensino.

Tabela 16. Gênero

$$
\begin{array}{|l|l|}
\hline \text { Masculino } & 12(26,1 \%) \\
\hline \text { Feminino } & 34(73,9 \%) \\
\hline
\end{array}
$$

Gráfico 16

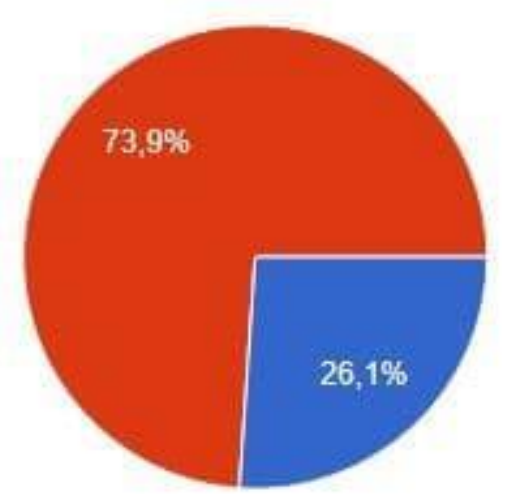

Masculino

Feminino

Fonte: dados obtidos no inquérito Google Forms.

A dominância do gênero feminino (34 - 73,9\%) não surpreende no ensino em geral e no nosso universo de inquiridos, particularmente; o gênero masculino regista-se quase em um terço $(12-26,1 \%)$.

Tabela 17. Habilitações literárias

\begin{tabular}{|l|l|l|}
\hline $\begin{array}{l}\text { Sem } \\
\text { licenciatura }\end{array}$ & $\mathbf{1 5}$ & $\mathbf{3 2 , 6 \%}$ \\
\hline Licenciatura & 12 & $26,1 \%$ \\
\hline Mestrado & 13 & $28,3 \%$ \\
\hline Doutoramento & 08 & $13,0 \%$ \\
\hline
\end{tabular}


Gráfico 17

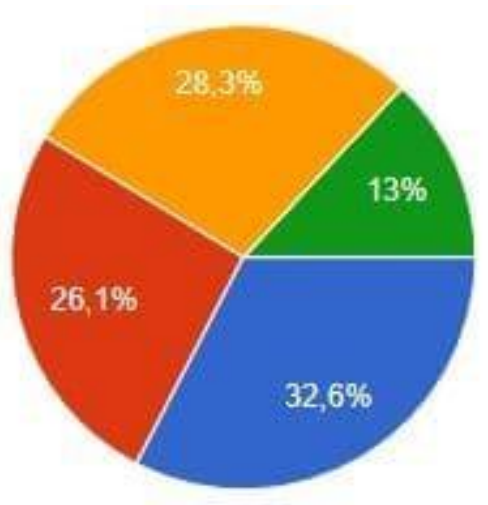

$$
\begin{aligned}
& \text { Sem licenciatira } \\
& \text { Licenciatura } \\
& \text { Mestrado } \\
& \text { Doutoramento }
\end{aligned}
$$

Fonte: dados obtidos no inquérito Google Forms

Os estudantes corresponderam em maior percentagem (32,6\%) seguidos pelos mestres $(28,3 \%)$ e pelos licenciados $(26,1 \%)$; finalmente, os doutorados $(13 \%)$. A ordem é coerente, no entanto,

a percentagem de inquiridos poderia ter sido mais elevada atendendo a uma dimensão que tem potencialidades de alterar o rumo da Educação.

Tabela 18. Concelho onde exerce a atividade profissional

\begin{tabular}{|l|l|}
\hline Fafe & $\mathbf{1 4}(\mathbf{4 2 , 4 \% )}$ \\
\hline Paredes & $06(18,1 \%)$ \\
\hline Guimarães & $05(15,1 \%)$ \\
\hline Santa Maria da Feira & $03(09,0 \%)$ \\
\hline Braga & $01(03,0 \%)$ \\
\hline Vila Verde & $01(03,0 \%)$ \\
\hline Porto Santo & $01(0,03 \%)$ \\
\hline Desempregada & $01(03,0 \%)$ \\
\hline Inválido (GCI)[5] & $01(03,0 \%)$ \\
\hline
\end{tabular}


Gráfico 18

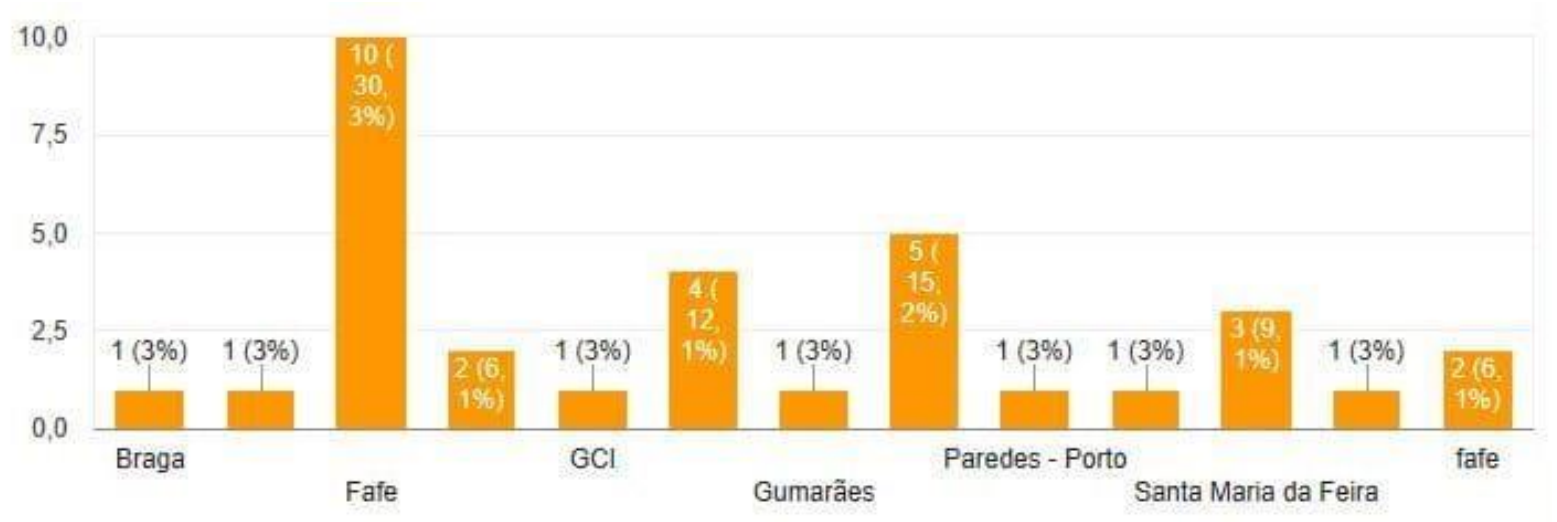

Fonte: dados obtidos no inquérito Google Forms

Fafe regista, com naturalidade, a maior percentagem (42,4\% - Fafe; GCl; barra acima de S.ta Maria da Feira; e Fafe), sobrando para Paredes-Porto (18,1\%), S.ta Maria da Feira $(9,1 \%)$, Vila Verde $(3 \%)$ e Porto Santo $(3 \%)$ os restantes, procedentes de alunos das especializações, com grande probabilidade - totalizando $33,2 \%$, comprovativo de que a ESE tem uma oferta de qualidade apreciável.

\section{CONCLUSÕES}

Alinhando os resultados do inquérito, fixamos a dominância da perceção da Educação Artística (37\%); adicionando-a a Artes na Educação obtemos 63,1\%. Resta o esforço dos docentes e uma abertura alargada para a Educação pela Arte $(23,9 \%)$ - caminho destinado à autoeducação. É na ONU, em 2010, que se defende a Educação pela Arte e a Educação Artística (CASALS, 2012, p. 28-29).

Nos objetivos do processo educativo em Artes, as dimensões consolidar o movimento e a experiência e desenvolver a autoeducação têm valores semelhantes e completamse na ordem dos $85 \%$; os objetivos estão adequados à atualidade do ensino.

$\mathrm{Na}$ interdisciplinaridade e os seus contributos para a promoção das artes, a Expressão Plástica (91,3\%) - abaixo da Expressão Dramática (97,8\%) e da Expressão Musical $(95,6 \%)$ - admira por ser uma das áreas mais trabalhadas no ensino e na Arteterapia. 
A Arteterapia como tratamento psicoterapêutico tem a opção da Musicoterapia (75\%) e da Expressão Plástica (65,2\%). Em vertentes de intervenção adequadas à Arteterapia, a opção incontestável centra-se na vertente educacional (100\%). A Arteterapia como um conceito familiar revela-se nas escolas do PE e um pouco mais de $50 \%$ no 1. CEB. Metade dos respondentes não conhece Projetos de Arteterapia em unidades de ensino e $26,1 \%$ não tem a certeza do conhecimento sobre este assunto. Fora do contexto escolar, metade dos inquiridos têm conhecimento de projetos em Arteterapia. Esta é uma das dimensões da qual há muito que aguardar em termos de qualidade e promoção da autoeducação.

Sobre as artes com crianças hospitalizadas, a música, o desenho, a pintura, a dança, o canto e o desporto, a maioria dos inquiridos (69,6\%) considera que todas as áreas despertam interesses distintos nas crianças. É a assunção plena da diferença em cada criança.

A valorização atribuída às atividades artísticas no desempenho escolar alcança $89,1 \%$, contribuindo para o desenvolvimento da criança e elevando a sua autoestima e capacidade de raciocínio; estes agentes concorrem para melhorias noutras matérias interdisciplinares; concorda totalmente que as atividades artísticas são uma prática a adotar em todas as unidades hospitalares chega a $60,9 \%$, faltando, provavelmente, uma informação mais sólida sobre os seus benefícios.

O papel das artes e das expressões no desenvolvimento de crianças com necessidades especiais, designadamente PEA (Perturbação do Espetro do Autismo) é capital para $(93,4 \%)$.

O perfil do respondente maioritário situa-se na faixa etária de $21-25$ anos $(23,9 \%)$; se juntarmos três grupos - até 20 - (8,7\%), $21-25(23,9 \%)$ e $26-30$ (6,5\%) atingimos 39\%; adicionando $41-45(19,6 \%)$ com mais de $45(21,7 \%)$ granjeamos $41,3 \%$, resultado que advirá dos professores que frequentavam as especializações na ESE.

Os estudantes, nas habilitações acadêmicas, correspondem a $32,6 \%$, seguidos de perto pelos mestres $(28,3 \%)$; depois, os licenciados $(26,1 \%)$ e os doutorados $(13 \%)$. 
Quanto à atividade profissional, Fafe regista 42,4\%, sobejando para ParedesPorto $18,1 \%$, S. ta Maria da Feira $(9,1 \%)$, Vila Verde $(3 \%)$ e Porto Santo $(3 \%)$, revelando a qualidade formativa da ESE.

\section{CONSIDERAÇÕES FINAIS}

Herbert Read foi capital para os movimentos defensores da Educação pela Arte em Portugal; no entanto, recorremos a estudos que versam a Educação pela Arte, mas sem incluírem aquele autor nas referências bibliográficas. Tal pode significar a aquisição de autonomia por parte de pedagogos que, exercitando projetos, chegaram a conclusões enriquecedoras para a Educação pela Arte.

Os objetivos delineados encontram eco nos resultados despontados: a) associar a Educação pela Arte à promoção da autoeducação (tabelas-gráficos 1, 3, 5, 10, 11; b) avaliar a promoção das artes no ensino, incluindo a interdisciplinaridade e a realização de eventos (tabelas-gráficos 1, 2, 3, 4, 14); c) justificar a dimensão da Arteterapia em contextos escolar e não escolar (tabelas-gráficos 5, 6, 7, 8; d) compreender o rendimento escolar com o desempenho nas atividades artísticas em contexto não escolar e em crianças com necessidades especiais (tabelas-gráficos 9, 10, 11, 12, 13).

As Expressões/Artes espoletam na criança os seus interesses motivacionais, tornando-se conscientes de si próprias como autoras e construtoras de imagens (HOHMANN e WEIKART, 1997 apud CANELAS, 2015). Os impulsos, as sensações e os sentimentos precisam de expressão livre. As experiências artísticas fornecem possibilidades cognitivas, afetivas, expressivas - como criação, reflexão e compreensão que favorecem a construção da identidade pessoal e social (FRÓIS et al., 2000 apud CANELAS, 2015).

Nos resultados, predomina a Educação Artística, ficando para os docentes uma abertura para a Educação pela Arte. Metade dos inquiridos não conhece projetos de Arteterapia em unidades de ensino; fora do contexto escolar, há manifestações de conhecimento de projetos em Arteterapia. Sobre as artes com crianças hospitalizadas, 
a Música, o Desenho, a Pintura, a Dança, o Canto e o Desporto, a maioria considera que todas as áreas despertam interesses distintos nas crianças. O papel das Artes e das Expressões no desenvolvimento de crianças com necessidades especiais é expressivo.

Acerca da questão de partida - Qual o papel da Educação pela Arte para a evolução do $P E$ e do $11^{\circ}$ CEB? - os resultados são animadores, mas, não chegando as imposições legislativas, o trabalho a fazer para promover a Educação pela Arte terá de ser realizado na base: educadores, professores, agentes socioculturais e restante

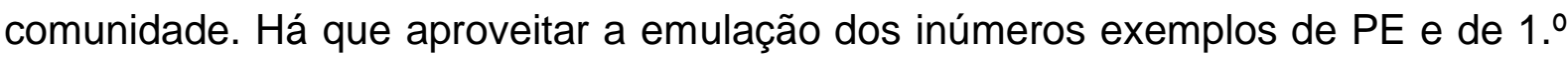
CEB para a sustentação de uma realidade que desejamos próxima, aproveitando os investimentos de investigadores e resultados que assomam no terreno.

É basilar que a Educação pela Arte alcance um estatuto digno como corolário de um empenhamento humanista, constituindo um instrumento para a autoeducação, estudo que aprofundaremos posteriormente. As dimensões artísticas serão mais visíveis com um reforço posicional de base mediante uma colaboração interdisciplinar sólida nas Artes/Expressões de molde a alcançar-se o patamar da Educação pela Arte, momento, entre outros, em que a criança sentirá os benefícios da autoeducação. Voltaremos, proximamente, a aprofundar algumas das dimensões aqui abordadas.

\section{REFERÊNCIAS}

BAHIA, Sara. Considerações sobre a educação para a arte e para a cultura, ou como levar Clio à escola. Revista Lusófona de Educação, Universidade de Lisboa, n.ำ 16, p. 47-58, 2010. Disponível em: <https://repositorio.ul.pt/bitstream/10451/2755/1/ClioRevistaLusofona\%2C2010.pdf>. Acesso em: 05 jan. 2020.

BARATA, Vanessa Miguel Xavier. 2014. 203f. Eu sou arte. O lugar das expressões no desenvolvimento de crianças com NEE. Um estudo de caso com crianças com PEA. Dissertação (Mestrado em Educação Especial - Domínio Cognitivo e Motor) - ESE do Instituto Politécnico de Castelo Branco, 2014. Disponível em: 
<https://repositorio.jpcb.pt/handle/10400.11/2497> Acesso em: Acesso em: 05 jan. 2020.

CÂMARA, Maria Margarita Gomes. Contributos da experiência da Educação pela Arte (1971-1982). Para a Educação Artística em Portugal. 2008. 57f. Dissertação (Mestrado em Educação Artística) - Faculdade de Ciências Sociais e Humanas, Universidade do Algarve, Faro, 2007. Disponível em: <http://hdl.handle.net/10400.1/455> Acesso em: 12 abr 2020.

CARREIRA, Joana Filipa Formiga. 2013. 88f. A Arte: uma viagem mágica com Miró. Dissertação (Mestrado em Ciências da Educação - Educação pela Arte) - ESE João de Deus, Lisboa, 2013. Disponível em: <https://comum.rcaap.pt/bitstream/10400.26/5083/1/A\%20Arte\%2c\%20uma\%20viag em\%20m\%c3\%a1gica\%20com\%20Mir\%c3\%b3.pdf> Acesso em: 10 jun 2020.

CARVALHO, Ruy. A estética da epistemologia: Metodologia da fundamentação em arteterapia/psicoterapia. Revista Portuguesa de Arteterapia. Arte Viva, Lisboa, n.. 8, p. 66-134, out. 2018. Disponível em: <http://arte-terapia.com/wpcontent/uploads/2013/09/Revista-Arte-Viva-8-2018.pdf>. Acesso em: 10 jun 2020.

CASALS, Diana Rodrigues. O Chapitô Criação e Criador da Educação pela Arte em Portugal. 2020. 35f. Dissertação de mestrado - Faculdade de Ciências Sociais e Humanas, Universidade Nova de Lisboa, 2012. Disponível em: <http://hdl.handle.net/10362/7540> Acesso em: 11 maio 2020.

\section{CATTERALL, James S. A experiência artística melhora o desempenho escolar?} Resposta a Eisner, 2012.03.12. Disponível em: <http://artenaescola.org.br/sala-deleitura/artigos/artigo.php?id=69342>. Acesso em: 15 out. 2019.

CERRUTO, E. Dançaterapia. A dança para todos. Centro de Formação Internacional em Dançaterapia - DMT (s.d.). Disponível em: <http://dancaterapiadmt.com.br/artigos/Dan\%E7aterapia!!!\%20\%20A\%20dan\%E7a\%20para\%20todos.p df>. Acesso em: 15 out. 2019. 
CONCEIÇÃO, Raquel Sofia Guerreiro da. A Arte na Educação Infantil. A importância para o Desenvolvimento Infantil. 2015. 55f. Dissertação (Mestrado de qualificação para a docência em Educação pré-escolar) -Instituto Superior de Educação e Ciências, Lisboa, $2015 . \quad$ Disponível em: <https://comum.rcaap.pt/bitstream/10400.26/21565/1/Relat\%C3\%B3rio\%20final.pdf> Acesso em: 20 set. 2019.

CRUZ, Maria Inês Santos Silva. A expressão pela arte no bem-estar da criança em internamento prolongado. 2012. 76f. Dissertação (Mestrado em Ciências da Educação Educação pela Arte) - ESE de João de Deus, Lisboa, 2012. Diusponível em: <https://comum.rcaap.pt/handle/10400.26/3827> Acesso em: 15 jan. 2020.

EÇA, Teresa Torres Pereira de. Educação através da arte para um futuro sustentável. Cad. CEDES, Campinas, vol. 30, n. 80, p. 13-25, jan.-abr. 2010. Disponível em: <https://doi.org/10.1590/S0101-32622010000100002>. Acesso em: 10 set. 2019.

EÇA, Teresa Torres de. Del arte por el arte a las artes comprometidas con las comunidades: paradigmas actuales entre educación y artes. Pensam palabra, Bogotá, obra n.. 6, p. 16-23, jun, 2016. Disponível em: <http://www.scielo.org.co/pdf/ppo/n16/n16a03.pdf>. Acesso em: 05 out. 2019.

EDUCAÇÃO PARA RECORDAR. 27 abr 2011. Calvet de Magalhães. Memórias de um mestre. Disponível em: <https://largodoscorreios.wordpress.com/2012/11/05/calvet-de-magalhaes-4/>. Acesso em: 15 out. 2019.

EDUCAMAIS. Quem é o dramaterapeuta? (s.d.). Disponível em: <http://educamais.com/quem-e-o-dramaterapeuta/>. Acesso em: 23 out. 2019.

ESTEVES, C. R. Pedagogia hospitalar: um breve histórico, 2013. Disponível em: <https://pedagogiaaopedaletra.com/wp-content/uploads/2013/06/HISTÓRICODA-PEDAGOGIA-HOSPITALAR.pdf>. Acesso em: 10 out. 2019. 
FILHO, Aldo Victorio, BULCÃO, Heloisa Lyra, BATISTA, Leonardo Moraes. O Espaço na/da Arte e na/da Educação como (Re)Existência. Educação e Realidade, Porto Alegre, vol. 44, n.․ 3, e84913, 15 p. 2019. Disponível em: <http://dx.doi.org/10.1590/2175-623684913>. Acesso em: 02 nov. 2019.

FREITAS, Henrique.; JANISSEK-MUNIZ, Raquel; MOSCAROLA, J. Modelo de formulário interativo para análise de dados qualitativos. Revista de Economia e Administração, Brasil, S. Paulo-SP, v. 4, oo 1, p. 27-48, janeiro/março, 2019. Disponível em: <https://adrodomus.blogspot.com/2008/06/mtodo-quantitativo-versusmtodo.html>. Acesso em: 04 jan. 2019.

GOMES, Carla Sofia Martins. A rua onde eu moro.... Um projeto interdisciplinar no 1 Ciclo do Ensino Básico. 2020. 80f. Dissertação (Mestrado em Educação PréEscolar e Ensino do 1ํㅡㄹ Ciclo do Ensino Básico), ESE de Setúbal, 2014. Disponível em:

https://comum.rcaap.pt/bitstream/10400.26/7791/1/Projeto\%20de\%20Investigação_ Carla\%20Gomes_120140002_VersãoDefinitiva.pdf> Acesso em: 03 mar 2020.

KEEL, J. Herbert Read on Education through Art. Journal of Aesthetic Education, 3 (4), 47-58, 1969. Doi:10.2307/3331429. Disponível em: $<$ https://www.jstor.org/stable/3331429?seq=1\#metadata_info_tab_contents>. Acesso em: 10 jun. 2020

LUCAS, Paula Cristina da Costa . Encontros sonoros: musicoterapia com crianças e jovens em acolhimento institucional. 2012. 73f. Dissertação (Mestrado em Musicoterapia) - Instituto de Psicologia e Ciências da Educação, Faculdade de Ciências, Universidade Lusíada de Lisboa. Disponível em: <http://hdl.handle.net/11067/358> Acesso em: 12 out. 2019.

MATEUS, Raquel; DAMIÃO, Maria Helena; FESTAS, Maria Isabel; MARQUES, Elisa. Educação estética e artística no currículo português do 1.0 ciclo do ensino básico: uma via de concretização. Coimbra: Imprensa da Universidade de Coimbra, 
2017, p. 229-242. Disponível em: <http://hdl.handle.net/10316.2/41800>. Acesso em: 04 fev. 2020.

MEIRA, Carla Maria Moreira Candeias. 2015. 72f. A Escola Superior de Educação pela Arte e o contributo do Dr. Arquimedes da Silva Santos. Dissertação (Mestrado em Educação Artística), Faculdade de Belas-Artes, Universidade de Lisboa, 2015.2 Disponível em: <https://repositorio.ul.pt/bitstream/10451/23564/2/ULFBA_TES_865.pdf >. Acesso em: 02 mar 2020.

MONTEIRO, Raquel Sofia Carvalho. 2016. 35f. A musicoterapia em contexto escolar: perturbações do comportamento, espectro do autismo e multideficiência. Dissertação (Mestrado em M u s i c o t e r a p i a) - FCHS, Universidade Lusíada de Lisboa, 2017. Disponível em: <http://repositorio.ulusiada.pt/bitstream/11067/2920/4/mmt_raquel_monteiro_disserta cao.pdf> Acesso em: 02 mar 2020.

MOVEA (Movimento Português de Intervenção Artística e Educação pela Arte). Atividades em movimento. Disponível em: <https://movea.pt/>. Acesso em: 12 out. 2019.

PLANO NACIONAL DAS ARTES. Uma estratégia um manifesto (2019-2024). Disponível em: <https://www.portugal.gov.pt/downloadficheiros/ficheiro.aspx?v=00a06c3f-f066-4036-adc2-b030b946e6ba>. Acesso em: 20 jun. 2020.

REIS, Alice Casanova dos. Arteterapia: a arte como instrumento no trabalho do psicólogo. Psicologia: ciência e profissão, Brasília, vol. 34, n. ำ1, p.142-157, janmarço, 2014. Disponível em: <http://dx.doi.org/10.1590/S141498932014000100011>. Acesso em: 15 jun. 2019.

RIBEIRO, Mónica Sofia Medina. 2019. 93f. Ateliê de arte com crianças de risco. Mestrado (Ciências de Educação Especialidade Em Educação pela Arte) - ESE de João de Deus, Lisboa, 2012. Disponível em: < 
https://comum.rcaap.pt/bitstream/10400.26/4093/1/MonicaRibeiro.pdf>. Acesso em: 02 dez. 2019.

ROCHA, Manuela José Pinela da. Arteterapia no Ensino Básico. 2010. 30f. Dissertação (Mestrado em Ensino da Educação Visual e Tecnológica no Ensino Básico) - ESE do Instituto Politécnico de Bragança, 2010. Disponível em: < https://bibliotecadigital.jpb.pt/bitstream/10198/3315/1/Relat\%c3\%b3rio\%20Final.pdf> Acesso em: 05 jan. 2020.

SALDANHA, Gilda Maria Maia Martins; SIMÕES, Reguna Regina Rovigati. Educação escolar hospitalar: o que mostram as pesquisas? Rev. Bras. Ed. Esp., Marília, v. 19, n. $. \quad 3, \quad$ p. 447-464, jul-set. 2013. Disponível em: $\leq$ https://www.academicoo.com/educacao-escolar-hospitalar-o-que-mostram-aspesquisas/.> Acesso em: 20 nov. 2019.

SANTOS, Maria Emília Brederode, MAGALHÃES, Calvet de. Movimento da Educação pela Arte. In Jornal de Letras, 12.10.2013. Disponível em: $<$ https://inquietacoespedagogicasii.blogspot.com/2013/12/publicado-no-jl-dedezembro-calvet-de.html>. Acesso em: 04 jan. 2020.

SOUSA, Alberto B. Educação pela arte e artes na educação. Bases psicopedagógicas. Lisboa: Instituto Piaget, 2003, vol.1.

SOUSA, Alberto B. Educação pela arte e artes na educação. Drama e dança. Lisboa, Instituto Piaget, 2003, vol. 2.

SOUSA, Alberto B. Educação pela arte e artes na educação. Música e artes plásticas. Lisboa, Instituto Piaget, 2003, vol. 3.

VAZ, Márcia Andreia de Oliveira. 2015. 69f. Expressões Artísticas e Educação Inclusiva: Práticas Educativas dos Docentes do 1. Ciclo do Ensino Básico. Dissertação (Mestrado em Ciências da Educação: Educação Especial - Domínio Cognitivo e Motor) - Universidade Fernando Pessoa, 2015. Disponível em: 
<https://bdigital.ufp.pt/bitstream/10284/4785/1/Disserta\%C3\%A7\%C3\%A3o_de_Mest rado_M\%C3\%A1rcia_Vaz.pdf >. Acesso em: 04 out. 2019.

\section{APÊNDICE - REFERÊNCIAS DE NOTA DE RODAPÉ}

1. Britânico, poeta, anarquista e crítico de arte e de literatura, Herbert Read foi o primeiro Presidente da Associação Internacional de Educação pela Arte, criada em 1954.

2. https://largodoscorreios.wordpress.com/2012/11/05/calvet-de-magalhaes-4/.

3. A página web (https://movea.pt/) destaca Arquimedes da Silva Santos (Nunca propusemos qualquer estrita definição, antes aceitando uma conceção geral que interrelacione conceitos vagos e vastos de educação e de arte numa perspetiva de quem considera, sobretudo e para além das palavras, a importância da atividade pedagógica pelas expressões artísticas no desenvolvimento, bio-sócio-psicologicamente, de crianças e adolescentes.) e Herbert Read (A arte deve ser a base da educação).

4. https://movea.pt/

5. https://www.portugal.gov.pt/download-ficheiros/ficheiro.aspx?v=00a06c3ff066-4036-adc2-b030b946e6ba

6. Musa da mitologia grega.

7. Ainda precisamos de recorrer aos meados do século XX...

Enviado: Julho, 2020.

Aprovado: Agosto, 2020. 